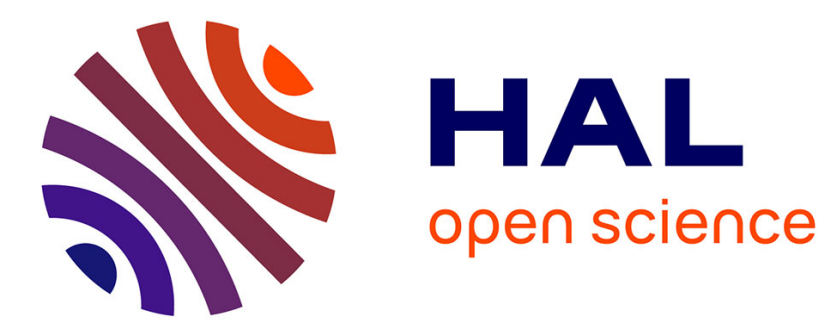

\title{
Beef tenderness and intramuscular fat proteomic biomarkers: Effect of gender and rearing practices
}

Brigitte Picard, Mohammed Gagaoua, Marwa Al Jammas, Muriel Bonnet

\section{To cite this version:}

Brigitte Picard, Mohammed Gagaoua, Marwa Al Jammas, Muriel Bonnet. Beef tenderness and intramuscular fat proteomic biomarkers: Effect of gender and rearing practices. Journal of Proteomics, 2019, 200, pp.1-10. 10.1016/j.jprot.2019.03.010 . hal-02627558

\section{HAL Id: hal-02627558 \\ https://hal.inrae.fr/hal-02627558}

Submitted on 22 Oct 2021

HAL is a multi-disciplinary open access archive for the deposit and dissemination of scientific research documents, whether they are published or not. The documents may come from teaching and research institutions in France or abroad, or from public or private research centers.
L'archive ouverte pluridisciplinaire HAL, est destinée au dépôt et à la diffusion de documents scientifiques de niveau recherche, publiés ou non, émanant des établissements d'enseignement et de recherche français ou étrangers, des laboratoires publics ou privés.

\section{(ㄷ)(1) $\$$}

Distributed under a Creative Commons Attribution - NonCommercial| 4.0 International 

6

\section{Beef tenderness and intramuscular fat proteomic biomarkers: effect of gender and} rearing practices

Brigitte Picard*, Mohammed Gagaoua**, Marwa Al Jammas, Muriel Bonnet

Université Clermont Auvergne, INRA, VetAgro Sup, UMR Herbivores, Saint-GenèsChampanelle, France

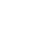

\section{Correspondence:}

* Dr. Brigitte Picard: brigitte.picard@inra.fr

ORCID: 0000-0002-8075-671

\section{ABSTRACT}

This study analyzed the effect of gender on the abundances of 20 protein biomarkers of tenderness and/or intramuscular fat content in five muscles: Longissimus thoracis, Semimembranosus, Rectus abdominis, Triceps brachii and Semitendinosus, from cows and steers of the Protected Designation Origin Maine Anjou. The protein abundances were quantified using Reverse Phase Protein Array with specific validated antibodies. Among the 20 studied proteins, the abundance of 8 biomarkers involved in energetic metabolism, contraction and cellular stress, was different according to gender. The gender effect was different depending on the muscle type with greater abundances in Semitendinosus, Rectus abdominis and Longissimus thoracis muscles. On the basis of animal characteristics and rearing factors, three rearing practices classes were identified for cows. Among the factors, fattening duration modified the abundance of 12 proteins mainly in Triceps brachii muscle. A positive correlation between the abundance of the small HSP20 and slaughter age was observed in the 5 muscles. Two proteins, Four and a half LIM domains 1 (FHL1) and Glycogen phosphorylase (PYGB) appeared to be muscle, gender and rearing practices independent. These results constitute valuable data to understand how to manage beef quality by controlling these different factors.

5 Keywords: Beef proteome, Gender, Skeletal muscles, Rearing factors, Proteomics, Reverse 


\section{SIGNIFICANCE}

38 This study is the first to compare the relative abundance of 20 proteins previously 39 identified as biomarkers of tenderness and/or intramuscular fat (IMF) content of beef meat 40 between cows and steers among 5 different muscles. Its originality is in the use of Reverse

41 Phase Protein Array for fast quantification of the proteins and the integration of data from 42 rearing factors, carcass characteristics and biomarkers of meat qualities. The findings provide 43 evidence for modulating biomarker levels by controlling the choice of animal type and rearing 44 factors according to the type of muscle that would produce animals with the desired meat 45 qualities. 


\section{Introduction}

The control of meat qualities is a societal issue that concerns all the meat sectors. Meat qualities are defined by a set of intrinsic and extrinsic properties where the former correspond to safety, health, convenience, nutritional and sensorial qualities; and the later are associated with the product and production system characteristics from the farm-to-fork, including animal welfare, carbon footprint and marketing variables (for review: [1-3]). For beef meat, the most crucial quality traits are tenderness and marbling associated with intramuscular fat (IMF) content. Tenderness defined as the ease with which meat can be sliced or chewed, is a multifactorial quality criterion the most variable and therefore the most difficult to control or predict. The appreciation of beef tenderness is generally positively associated with IMF content, the decrease in IMF content can also reduce tenderness [4]. Indeed, a minimum amount of IMF is needed for the expression of beef flavor as well as better tenderness [5]. IMF also plays an important role in beef juiciness, meat with high IMF content is always less dry than lean meat. Despite industry efforts to control the eating quality of beef, a high level of variability remains in these quality traits, which is one reason for consumer dissatisfaction. Thus, for producers and consumers, the control and management of beef tenderness and IMF content constitute a challenging task for better sustainability of the beef sector.

The large literature reported that those beef qualities are the result of complex biological mechanisms involved in muscle biochemistry in the live animals and after slaughtering during the aging period $[6,7]$. Over the last decades, numerous studies have analyzed the factors affecting these traits. The effect of factors related to the animal and its production systems such as muscle type, breed, age, sex, physiological stage of animals, nutritional diet, physical activity and fattening duration has been investigated [2, 8]. The earlier results reported that early maturing Anglo-Saxon breeds such as Aberdeen Angus or Japanese black cattle, are characterized with high degree of fatness, on the contrary late maturing breeds such as French 
71 beef breeds or double muscled cattle, have high muscle yield and low fatness scores [9]. The development of adipose tissues in some specific muscles appears to disorganize the muscle structure and contributes to tenderization of highly marbled beef during the late fattening period [10]. Increasing age seems to be favorable for juiciness and flavor (due to more intramuscular fat), but unfavorable for tenderness due to connective tissue characteristics despite an attenuation of this effect by high amounts of IMF [11]. Furthermore, gender plays an important role. For example, at the same age, females provide more flavorful, tenderer and intense color beef than steers or bulls[12]. Compared to beef from young bulls, meat from steers contains more IMF $[12,13]$. In the large literature, many controversies have been reported regarding the relationships between rearing factors and quality traits, with many conflicting results $[8,12,14$, 15] and today there is still no reliable online tools to predict these quality traits and deliver consistent quality beef for consumers. In this context, researches were conducted during the last 15 years to better understand the biological mechanisms underpinning tenderness and IMF variability to propose indicators or biomarkers which could be used for their prediction and/or management soon after slaughter of the animals [16, 17]. "Omics" approaches which allow a large number of genes, proteins or metabolites to be simultaneously studied without any $a$ priori, have been extensively applied (for review [16, 18]). These approaches had revealed that large amount of macromolecules may be potential molecular indicators of muscle mass and growth performance [19], sensory attributes [20-23] or marbling of meat [24, 25]. The question is now how to modulate them in order to control and manage beef quality. The expression or abundance of these biomarkers could be modulated through rearing factors. As the control of the zootechnical performance of animals and the quality of their products is of major economic importance in the context of beef sustainability, the aim of this study was to analyze the gender effect by comparing cows $v s$. steers and link with the rearing factors on the relative abundance of 20 biomarkers of tenderness and/or IMF content in 5 muscles. The proteins were quantified 
using the Reverse Phase Protein Array (RPPA) on 101 Protected Designation Origin (PDO) Maine-Anjou cattle [8, 21, 26]. A classification based on rearing factors was applied as described by Gagaoua et al $[8,22]$ to identify rearing practices classes. Then, carcass properties and relative abundances of the biomarkers were analyzed for each class among 5 muscles. The results revealed new insights that could be applied for a better understanding of the biological pathways involved in meat quality according to gender and rearing practices.

\section{Materials and Methods}

\subsection{Animals, handling and slaughtering}

A total of 101 cattle including 86 cows and 15 steers from the French PDO (Protected Designation of Origin) Maine-Anjou, using "Rouge des Prés" breed [21], were collected [26]. The PDO Maine-Anjou animals originated in the northwestern part of France from a cooperative of livestock farmers located in the department of Maine-et-Loire. This breed was the second (since 2004) among the four breeds allowed to be used in France for PDO meat production. It is composed of around $80 \%$ of cows (justifying the high number of animals in this study), younger than 10 years of age, having calved at least once and a minimal carcass weight of $380 \mathrm{~kg}$. Steers over 30 months of age with a carcass weight of $400 \mathrm{~kg}$ minimum can also be found (20\%). PDOs are of special importance for the valorization of local breeds, and the specifications of animal products under PDO are paid increasing attention [21]. The rearing practices of each animal were surveyed by a questionnaire as detailed in Gagaoua et al. [8] based on the study by Couvreur et al. Briefly, the questionnaire included variables about (i) the finishing period [part of hay, haylage, and/or grass in the finishing diet (\% w/w); total amount of concentrate $(\mathrm{kg})$; fattening duration (days); physical activity of the animals (\% days out)] and (ii) the animal characteristics by the age at slaughter in months. Those variables were used to identify rearing practices as detailed in the statistical section of this manuscript. 
Before slaughter, all animals were food deprived for $24 \mathrm{~h}$ and had free access to water. The

121 slaughtering was performed in the same industrial abattoir (Charal, Sablé sur Sarthes, France).

122 The animals were stunned using captive-bolt pistol prior to exsanguination and dressed

123 according to standard commercial practices. The slaughtering was also performed in

124 compliance with the French welfare regulations and respecting EU regulations (Council

125 Regulation (EC) No. 1099/2009).

126 After slaughter, the carcasses were characterized and graded according to the European beef

127 grading system (CE 1249/2008). Thus, information for each carcass were measured, namely hot

128 carcass weight (HCW, kg), EUROP conformation score (EUROP grid), carcass fat weight and

129 fat to muscle ratio (\% w/w) as described by Gagaoua et al. [11, 27].

\subsection{Muscle sampling}

131 The carcasses were not electrically stimulated and they were chilled at 3 to $4^{\circ} \mathrm{C}$ until $24 \mathrm{~h}$

132 post-mortem. The right half carcass was used for muscles measurements. Then, aliquots of five

133 muscles: Longissimus thoracis (LT), Semimembranosus (SM), Rectus abdominis (RA), Triceps

134 brachii (TB) and Semitendinosus (ST), from each carcass of the 101 PDO Maine Anjou cattle

135 were sampled. These heterogeneous muscles were chosen according to their differences in

136 contractile and metabolic type [26]. The LT muscle was excised from the $6^{\text {th }}$ rib as detailed by

137 Gagaoua et al. [27]. As the samples were for omics biomarkers analysis, the muscles (an

138 approximate of $2 \mathrm{~g}$ ) trimmed of connective and superficial fat tissue were immediately and

139 carefully frozen in liquid nitrogen and stored at $-80^{\circ} \mathrm{C}$ until analysis following the protocol

140 previously described by Picard et al. [26].

\subsection{Protein biomarkers quantification by Reverse Phase Protein Array}

142 The relative abundance of 20 protein biomarkers of tenderness and/or IMF content was

143 measured in the 5 muscles by the Reverse Phase Protein Array (RPPA) recently described by 
144 our group $[20,22,26]$. The specificity of the 20 antibodies on bovine muscle and their

145 conditions of use have been previously defined by western blotting which uses the same 146 technical principle as the RPPA method [26]. Briefly, the samples were firstly disrupted in a

147 Laemmli buffer containing $50 \mathrm{mM}$ Tris $\mathrm{pH}=6.8,2 \%$ SDS, 5\% glycerol, $2 \mathrm{mM}$ DTT, $2.5 \mathrm{mM}$

148 EDTA, 2.5 mM EGTA, 1x HALT Phosphatase inhibitor (Perbio 78420), Protease inhibitor

149 cocktail complete MINI EDTA-free (Roche 1836170, 1 tablet/10 mL), 2 mM Na $3 \mathrm{VO}_{4}$ and 10

$150 \mathrm{mM} \mathrm{NaF}$, using a Precellys (Bertin). Extracts were then boiled for $10 \mathrm{~min}$ at $100^{\circ} \mathrm{C}$, sonicated

151 to reduce viscosity and centrifuged $10 \mathrm{~min}$ at $15000 \mathrm{rpm}$. The supernatant was harvested and

152 stored at $-80^{\circ} \mathrm{C}$. Protein concentration was determined using the Pierce BCA reducing agent

153 compatible kit (ref 23252).

154 The sample extracts were then deposited onto nitrocellulose covered slides (Supernova, 155 Grace Biolabs) using a dedicated arrayer (2470 arrayer, Aushon Biosystems). Four serial 156 dilutions, ranging from 2000 to $250 \mu \mathrm{g} / \mathrm{ml}$, and two technical replicates per dilution were 157 printed for each sample. Arrays were labeled with each of the 20 specific antibodies or without 158 primary antibody (negative control), using an Autostainer Plus (Dako) as detailed in our 159 previous papers $[20,22,26]$. After protein quantification by RPPA, the raw data were 160 normalized using Normacurve following the procedure described by [28], which normalizes for

161 fluorescent background per spot, a total protein stain and potential spatial bias on the slide.

162 Next, each RPPA slide was median centered and scaled (divided by median absolute deviation).

163 We then corrected for remaining sample loadings effects individually for each array by 164 correcting the dependency of the data for individual arrays on the median value of each sample 165 over all 20 arrays using a linear regression.

\section{2.5. Statistical analysis}

167 The statistical analyses were performed using SAS statistical software (SAS 9.1, SAS 168 Institute INC, Cary, NC, USA) and XLSTAT 2017.19.4 (AddinSoft, Paris, France). Before 
analysis, raw data means were scrutinized for data entry errors and outliers. Normal distribution

170 and homogeneity of the dataset was first tested by the Shapiro-Wilk test $(P>0.05)$. The PROC

171 GLM procedure of SAS was then used to study the muscle type (5 muscles), gender (cows vs.

172 steers) and interactions effects on the relative abundances of the proteins. Significant

173 differences among muscles were performed using Tukey's test at a significance level of $P<$

174 0.05. Similarly, the protein abundances were further compared between the two genders within

175 each muscle separately and the effect of rearing practices on the abundances of the 20 proteins

176 was analyzed for both cows and steers.

177 For the 86 cows only, rearing practices classes were created using the statistical approach

178 described by Gagaoua et al. $[8,20]$ based on principal component analysis (PCA) combined to

$179 k$-means clustering. For that, the fattening period data (part of hay, haylage and/or grass in the

180 finishing diet $(\% \mathrm{w} / \mathrm{w}))$; total amount of concentrate $(\mathrm{kg})$; duration (days) and physical activity

181 (\% days out) of the animals at the farm were used [8]. Two factors with eigenvalues $>1.0$ were

182 extracted on the basis of the scree plot and evaluation of the factor loading matrix after

183 orthogonal rotation. These allowed us to identify using Z-scores on the two axis 3 rearing

184 practices that were named to simplify the discussion as follow: Class $1=$ "Hay class"; Class $2=$

185 "Grass class", and Class $3=$ "Haylage class", respectively (Table 3). Z-scores represent the

186 deviation of each observation relative to the mean of the corresponding individual in each

187 rearing practice and were calculated using PROC STANDARD of SAS that standardizes data to

188 a mean of 0 and standard deviation of 1 . These normalized data were used to build PCAs to

189 depict the relationships between the rearing practices of the 86 PDO Maine-Anjou cows with i)

190 animal, rearing factors and carcass characteristics, and with ii) the 20 protein biomarkers from

191 the 5 muscles quantified by RPPA technique within the rearing factors. The Kaiser-Meyer-

192 Olkin (KMO) measure, known also as Kaiser's Measure of Sampling Adequacy (MSA) was

193 applied to test the validity of the sampling [29]. Subsequently, unsupervised hierarchical 
194 clustering heatmap was generated using the same data to assess the differences among the 5

195 muscles based on the normalized data for each rearing practice. For the 15 steers, only two 196 rearing practices were identified (grass $(n=5)$ and haylage $(n=10)$ ) and were considered in the 197 analyses in same manner than cows.

198 Finally, the PROC CORR of SAS after Z-scores calculation was used to compute the 199 Pearson's correlations of coefficients between the 20 proteins and the animal, rearing factors 200 and carcass characteristics of the whole data of the 86 cows. Correlation coefficients were 201 considered significant at $P<0.05$.

\section{Results and discussion}

\subsection{Gender effect}

The gender (cows $v s$. steers) had a highly significant effect on the relative abundance of 8 proteins among the 20 analyzed: HSP20, PGK1 $(P<0.001)$, PRDX6, ALDOA $(P<0.01)$, MDH1, TPI1, MyHC-IIX, TNNT1 $(P<0.05)$ (Table 2). All muscle combined, the cows comparatively to steers had significantly $(P<0.01)$ higher abundance of HSP20, ALDOA, MDH1, MyHC-IIX, and lower abundance of PGK1, PRDX6, TPI1 and TNNT1 (Table 2).

Of the 20 proteins analyzed, only HSP20 had an abundance that differed between steers and cows irrespective of the considered muscle. An interaction of muscle x gender was observed for this protein (Table 2) which was more abundant in cows for LT, SM, ST muscles, and was not

212 different in RA and TB. Figure 1 illustrates higher differences between muscles in steers than in cows. In the two genders, the abundance of HSP20 was the highest in RA muscle. On another

214 hand, the abundances of CRYAB, HSP27, HSP40, HSP70-1, FHL1, TRIM72, PYGB, 215 ALDH1A1, ENO3, TTN, MLC1F and $\alpha$-tubulin were not different between steers and cows. 
type reported to modify the abundance of 16 of 20 proteins, only 4 proteins namely HSP40

219 (Heat shock protein), FHL1 (Four and a half LIM domains protein 1), PYGB (Glycogen 220 phosphorylase B) and MDH1 (Malate dehydrogenase), were found to do not differ among the 5 221 muscles [26]. Thus, according to these two studies, HSP40, FHL1 and PYGB were not 222 modified either by gender or muscle type while HSP20, PRDX6, PGK1, ALDOA, MyHC-IIX, 223 TNNT1 and TPI1 showed both muscle and gender effects.

The analysis of gender effect in each of the 5 muscles showed that it was most important for ST, RA, and LT muscles. It is particularly significant for HSP20 which abundance between cows and steers was not modified in TB and RA muscles and was significantly different between the two genders for the three other muscles. In TB muscle, the abundances of 19 of 20 proteins were not different between cows and steers. This indicates that this muscle is insensitive to the sex or gender effect (Table 2). This result is coherent with previous data of our group showing no effect of castration on contractile and metabolic properties of TB muscle while the effect of castration was the greatest in ST and LT muscles [30], in accordance with

232 the results of the present study. Indeed, in the present study, the most important differences between the two genders were observed in ST muscle as the abundances of 8 proteins were 234 different between cows and steers, whereas 6 were different in LT and RA and 5 in SM muscle. 235 To our knowledge, very few studies in the literature have compared the muscle proteome 236 properties of cows comparatively to steers in different muscle types. Previous results of our 237 group showed that RA muscle of heifers comparatively to steers, was more oxidative with 238 greatest ICDH and COX activities and less glycolytic with a lowest LDH activity [21, 31]. 239 These data are coherent with the present results showing modifications of contractile [MyHC240 IIX (fast glycolytic isoform), TNNT1 (slow isoform)] and metabolic [ALDOA (glycolytic 241 enzyme involved in glycogen storage), MDH1 (involved in tricarboxylic acid cycle), PGK1 242 (glycolytic enzyme) and TPI1 (involved in gluconeogenesis and carbohydrate biosynthesis)] 
243 properties of the muscles between cows and steers. This effect could be explained mainly by 244 differences in sex hormones between the two genders. The effect of estrogens on skeletal 245 muscle properties has been largely studied in different species [32, 33]. Indeed, estrogens and 246 their receptors play key roles in the regulation of energy metabolism pathways, including 247 glucose transport, glycolysis, tricarboxylic acid cycle, mitochondrial respiratory chain, 248 adenosine nucleotide translocator and fatty acid $\beta$-oxidation and synthesis [34]. A higher insulin 249 sensitivity was also reported in female, and the ratio of glycolytic/oxidative enzyme activities 250 within skeletal muscle correlated negatively. These modifications in muscle physiology induced 251 by estrogens are in accordance with the modifications in protein abundances observed in this 252 study.

Among the differential proteins, HSP20 and PGK1 showed and all muscles confounded the 254 highest differences between the two genders (Table 2). To the best of our knowledge, only one 255 publication reported a higher abundance of HSP20 (HSPB6 gene) and a lower abundance of 256 PGK1 in muscle from women than men as observed for cattle in this study [35]. Few data are 257 available in the literature about the effect of castration or estrogens on HSPBC gene expression 258 (HSP20). In line to this scarcity of studies in the large literature, a recent review by Gianazza $e t$ 259 al. [36] reported that the first proteomic survey on the proteome of male $v$ s female serum in 260 humans is also as recent as 2010 [37]. Therefore, it is difficult to compare the findings of this 261 study to the literature.

262 The findings of HSP20 protein may be partly linked to its binding to structural proteins such 263 as TNNT1 [38]. These data are coherent with the differences observed between cows and steers 264 for both HSP20 and TNNT1. Moreover, earlier studies demonstrated that HSP20 is 265 phosphorylated in response to insulin in skeletal muscle [39] and the authors proposed HSP20 as a potential modulator of insulin's functions. The differences in TNNT1 abundance between cows and steers could be the consequence of insulin sensitivity induced by estrogens. The 
action of estrogen is also through circulating adipokines as adiponectin and leptin which levels

269 are higher in females [40]. These adipokines are involved in muscle metabolism and fat deposition.

The main effect of gender in the present study was observed for PGK1 as it is the only protein among the 20 analyzed which was more abundant in steers comparatively to cows in each of the 5 muscles. This protein is involved in glycolysis as it is the first ATP-generating enzyme in the glycolytic pathway, catalyzing the conversion of 1,3-diphosphoglycerate to 3phosphoglycerate. It has been recently shown that PGK1 translocates to the mitochondria where it specifically phosphorylates pyruvate dehydrogenase kinase [41]. These data are in accordance with a high effect of sex hormone on glucose metabolism [42] that would also be linked to IMF deposition within steers [43]. Several data of the literature indicated that castrated cattle have higher fast-twitch glycolytic fiber proportion and lower slow-twitch oxidative fiber than intact males.

\subsection{Effect of rearing practices}

282 The variance analysis showed that the abundance of very few proteins was modified by rearing practices (Table 3). In cow muscles, only 3 proteins were significantly different $(P<0.05)$ : PRDX6, PGK1, ALDOA, and 3 others showed tendencies $(P<0.1)$ : HSP20, ENO3, MDH1. In steer muscles, we observed no significant differences between the two rearing 286 practices for 18 proteins and only 2 tended to be different: ALDOA and ALDH1A1. Only the abundance of ALDOA was affected by rearing practices in both cows and steers. It is worthwhile to note that the abundance of this protein was also different among the 5 muscles in cows and in steers. An effect of gender was observed only in LT muscle with a lower abundance in LT of steers comparatively to cows. The results demonstrated that the effect of

291 rearing practices on the abundance of the 20 biomarkers is weak, and lower than the effect of gender which is weaker than muscle type effect. 
The analysis of animal and rearing factors on cows allowed to distinguish 3 rearing practices 294 classes that differed by 9 factors (Table 4). The most discriminating factors were animal 295 activity, percentage of grass, haylage or hay in the diet during the fattening period $(P<0.001)$ 296 (Table 4). Accordingly, these 3 classes were called "grass", "hay" and "haylage" [8]. For steers, 297 we have identified "grass" and "haylage" rearing practices only (data not shown) and they were 298 not different for any of the studied biomarkers, therefore the results are not discussed in the 299 following sections (Table 3).

300 Comparatively to the "hay" and "haylage" classes, the "grass" class was characterized by 301 higher animal activity, longer fattening period duration and the carcasses of the animals had a 302 lower conformation score (Table 4 and Figure 2a). The haylage class was characterized by a 303 higher carcass weight than the two other classes.

304 For the effect of rearing practices on the studied protein biomarkers, the "grass" class had an 305 impact mainly on the properties of the SM and ST muscles known as fast glycolytic muscles 306 (Figure 2b). This class was characterized by high relative abundance of MLC1F (fast isoform), 307 PRDX6 (an antioxidant enzyme) and of three glycolytic enzymes (PGK1, TPI1 and ENO3). 308 Hay finishing practices affected the properties of RA muscle known as slow oxidative muscle. 309 This class was characterized by high abundance of small Heat Shock Proteins (HSP20, 27 and 310 CRYAB) as well as HSP70-1A, TNNT1 (slow structural protein isoforms) and ALDH1A, and 311 by a low abundance of MyHC-IIX (fast glycolytic). Furthermore, the results revealed that LT 312 and TB muscles, known as mixed oxido-glycolytic muscles, were less impacted by rearing 313 practices than the 3 other muscles. Interestingly, the abundance of 3 proteins FHL1, MDH1 and 314 PYGB was not different among the 3 rearing practices classes whatever the muscle (Figure 3). 315 Abundance of HSP40 and $\alpha$-tubulin was modified in the Hay class only.

316 One of the main results of the present study is to show that rearing practices classes are 317 different according to the studied muscle. Grass class is composed mainly of SM and ST 
muscles (fast glycolytic muscles); haylage class groups LT and TB muscles (mixed oxydoglycolytic muscles) and hay class contains only RA muscle. These data indicate that the impact of rearing practices is muscle type dependent. In this study, the fast glycolytic muscles were the most impacted by grass finishing diet. These modifications are interesting in term of beef tenderness as well as other sensory qualities [44]. Indeed, we have recently showed that ST muscle is more tender when it is more fast glycolytic [45]. A recent study of our group showed that the LT muscle of Rouge de Prés cows with grass diet had lower proportions of IIX fibres (fast glycolytic and higher proportion of IIA fibres fast oxydo-glycolytic) [8]. An opposite effect of rearing practices on LT and ST muscles has already been observed. However, despite an opposite response, the effect of a grass finishing diet has a positive impact on tenderness in both muscles, since for LT, unlike ST, the less glycolytic are the most tender [45].

\subsection{Correlations between biomarkers and the carcass and rearing factors}

The correlation analyses, although they are weak but coherent, showed that among the 9 factors discriminating the 3 rearing practices classes of cows, fattening duration and age at slaughter had an influence on the protein abundances in the 5 muscles (Figure 4). Fattening duration modified the abundance of 12 among the 20 studied proteins (Figure 4). This effect

334 was the most important in TB muscle as the abundance of 6 proteins was modified. For TB 335 muscle, the abundances of MLC1F, PYGB, PRDX6 and FHL1 decreased when fattening duration increased whereas abundance of HSP70-1A and TTN increased. The abundance of PYGB was also modified in LT and ST muscles (with a negative correlation between fattening duration and PYGB abundance) but not in RA and SM muscles. HSP70-1A was modified also in RA but inversely in comparison with TB muscle. We observed also that the abundance of

340 ENO3 was inversely correlated with fattening duration in LT (positively) and SM (negatively). 341 The present abundance variations seem to be related to the composition of the fibrous part of 342 the diet and/or animal activity that was independent of the slaughter weight and age. These are 
consistent with previous observations by our group highlighting that fattening duration is the

344 most influencing rearing factors for meat quality, particularly tenderness $[2,8,11]$.

345 For slaughter age, the main effect observed was a positive correlation with the abundance of 346 HSP20 in the 5 muscles (Figure 4). It is the only protein which abundance was modified in the 347 same way in the 5 muscles with an increase with age at slaughter of the animals. Interestingly, 348 HSP20 discussed above to be affected by gender was the only protein which abundance was 349 modified in the same way in the 5 muscles. HSP20 belongs to a family of at least 10 different 350 small HSPs [17]. HSP20 is expressed in multiple tissues but it is more abundant in muscle [46]. In human and rat, an increase of its expression with age has been reported in accordance with 352 the present results $[47,48]$. This increase is considered in the literature as an essential cellular response to fiber aging; according to our results this response seems to be muscle type independent. The modifications of HSP20 abundances with slaughter age are in accordance with the modification of contractile and metabolic properties observed in aged muscles in cows and steers toward a shift from fast glycolytic to slow oxidative [8, 16, 45]. The main effect of slaughter age was observed for RA muscle with a correlation with the abundance of 5 proteins: positively with HSP20, FHL1, ALDH1A1, TNNT1 and negatively with MyHC-IIX. EUROP conformation and carcass weight were linked to the studied proteins in 4 muscles unless TB 360 muscle which was not influenced as any correlation with proteins abundances were observed 361 (Figure 4). The EUROP conformation had an impact mainly in SM muscle in which it was correlated with 4 proteins: positively with TTN, MDH1, TRIM72 and negatively with PGK1.

364 was correlated with 4 proteins in LT: positively with TPI1, negatively with HSP70-1A, MDH1, 365 PYGB. Total concentrate (in $\mathrm{kg}$ ) was correlated with proteins abundances in 4 muscles and no correlations were observed in LT muscle. It was negatively correlated with MDH1 abundance 
RA was negatively correlated with animal activity, no correlations were observed for the 3 other muscles. It was also negatively correlated with animal slaughter age in LT and SM. We observed that in LT muscle, the abundance of this protein was correlated negatively with 4 rearing factors: animal activity, $\%$ grass in the diet, carcass weight and fattening duration. On another hand, animal activity showed no correlations with the protein abundances of ST and TB muscles. In each of the three other muscles, animal activity was correlated with the abundances of 3 proteins.

Of the 5 muscles, the proteins in TB muscle were the least sensitive to variations in rearing practices. No correlations were observed with any proteins irrespective of rearing practices with EUROP conformation and carcass weight. Only one protein was correlated with the activity of the animals at the farm, mainly MLC-1F as well as with total concentrate for FHL1. However, TB muscle was the most modified muscle by fattening duration. On the contrary, RA and SM muscles were the most sensible to rearing practices as correlations with all rearing factors except grass\% for RA and haylage \% for SM, were observed.

\subsection{Proteins that did not discriminate the rearing practices classes with no difference among}

\section{muscles and genders}

The abundances of FHL1 (Four and a half LIM domains protein 1) and PYGB (Glycogen phosphorylase B) were not different between the three rearing practices classes. Interestingly, 386 the abundances of these proteins were not significantly different among the two genders and among the 5 muscles in cows and in steers. This indicates that the abundances of these proteins are muscle, gender and rearing practices independent.

FHL1 also named SLIM1 or KyoT1, belongs to the FHL protein family composed of four and a half Lin-11, Isl-1, and Mec-3 (LIM) domains. FHL LIM domains mediate protein -

391 protein interactions, scaffolding signaling proteins in the cytoplasm, and transcription factors in the nucleus. FHL1 as mentioned above is considered as a regulator of skeletal muscle mass, and 
strength enhancement by binding with the calcineurin-regulated transcription factor NFATc1 [49]. This protein is confined to the Z-line of skeletal muscle and its proteolysis is linked to the release of intact $\alpha$-actinin from bovine myofibrils and contributes to the weakening of the Z-line during meat tenderizing [50]. FHL1 may also interact with other biological pathways, namely metabolic enzymes [26, 51] in response to both hypoxia, apoptosis and oxidative stress [52]. This protein seems to play a fundamental role in muscle mass and muscular strength which could explain why its expression is relatively stable according to muscle, gender or rearing practices. For example, FHL1 increased the myostatin activity on a SMAD reporter and increased myostatin dependent myotube wasting [53]. According to these authors, FHL1 is expressed at higher levels in type II than in type I fibers raising the possibility that it contributes to the greater sensitivity of type II fibers to myostatin. However, these differences in fiber types expression were not observed among our 5 muscles as previously reported by our group [26]. On another hand, PYGB is a Glycogen Phosphorylase which catalyzes the glycogen degradation. Its activity is positively regulated by AMP and negatively regulated by ATP, ADP, and glucose-6-phosphate [6].The non-variation on this protein abundance would be due to a lack of an enhanced glycogen degradation by the factors considered in this publication.

\section{Conclusion}

This study is the first to consider the effect of gender and rearing practices on the abundances of biomarkers of tenderness and IMF content in five different muscles in cattle. The main results showed a higher effect of muscle type than gender or rearing practices. Moreover, factors associated with diet composition had few effects on proteins abundances. This knowledge constitutes important information to understand how to manage the expression of biomarkers of tenderness and IMF content according to gender and rearing practices. 


\section{Author contributions}

$419 \mathrm{BP}$ and $\mathrm{MB}$ defined the experiment design, managed the experiment, co-wrote the paper, and 420 approved the final draft of the manuscript. MG managed the database, analyzed the data, 421 prepared figures and/or tables, co-wrote the paper and approved the final draft of the 422 manuscript. MEJ participated in the database preparation. All authors collaborated with 423 interpretation and discussion of the results. All authors have given approval to the final versions 424 of the manuscript.

\section{Conflict of interest}

426 The authors declare no competing financial interest

\section{Funding Sources}

This experiment was conducted with funding from the regional council of Pays de Loire and SICA Rouge des Prés (France).

\section{Acknowledgements}

431 The authors thank Albéric Valais, Ghislain Aminot and Marlène Pécot from SICA Rouge des 432 Prés for muscle sampling and data on animal, rearing factors and carcass properties. They thank 433 Leanne De Koning, Aurélie Cartier and Bérengere Ouine from Institut Curie, RPPA Plateform,

434 Paris France, for the quantification of the biomarkers.

\section{References}

436 [1] Hocquette JF, Van Wezemael L, Chriki S, Legrand I, Verbeke W, Farmer L, et al. 437 Modelling of beef sensory quality for a better prediction of palatability. Meat science. $438 \quad 2014 ; 97: 316-22$.

439 [2] Gagaoua M, Monteils V, Picard B. Data from the farmgate-to-meat continuum including 440 omics-based biomarkers to better understand the variability of beef tenderness: An 441 integromics approach. J Agric Food Chem. 2018;66:13552-63.

442 [3] Gagaoua M, Picard B, Monteils V. Assessment of cattle inter-individual cluster 443 variability: the potential of continuum data from the farm-to-fork for ultimate beef tenderness 444 management. Journal of the Science of Food and Agriculture. 2019; In press. 
[4] Dransfield E, Martin J-F, Bauchart D, Abouelkaram S, Lepetit J, Culioli J, et al. Meat quality and composition of three muscles from French cull cows and young bulls. Animal Science. 2003;76:387-99.

[5] Wood JD, Richardson RI, Nute GR, Fisher AV, Campo MM, Kasapidou E, et al. Effects of fatty acids on meat quality: a review. Meat science. 2004;66:21-32.

[6] Ouali A, Gagaoua M, Boudida Y, Becila S, Boudjellal A, Herrera-Mendez CH, et al. Biomarkers of meat tenderness: present knowledge and perspectives in regards to our current understanding of the mechanisms involved. Meat science. 2013;95:854-70.

[7] Hocquette JF, Botreau R, Legrand I, Polkinghorne R, Pethick DW, Lherm M, et al. Winwin strategies for high beef quality, consumer satisfaction, and farm efficiency, low environmental impacts and improved animal welfare. Anim Prod Sci. 2014;54:1537-48.

456

457

458

459

460

461

462

463

464

465

466

467

468

469

470

471

472

473

474

475

476

477

478

479

480

481

482

483

[8] Gagaoua M, Monteils V, Couvreur S, Picard B. Identification of Biomarkers Associated with the Rearing Practices, Carcass Characteristics, and Beef Quality: An Integrative Approach. Journal of Agricultural and Food Chemistry. 2017;65:8264-78.

[9] Gotoh T, Albrecht E, Teuscher F, Kawabata K, Sakashita K, Iwamoto H, et al. Differences in muscle and fat accretion in Japanese Black and European cattle. Meat science. 2009;82:300-8.

[10] Nishimura T, Hattori A, Takahashi K. Structural changes in intramuscular connective tissue during the fattening of Japanese black cattle: effect of marbling on beef tenderization. $\mathrm{J}$ Anim Sci. 1999;77:93-104.

[11] Gagaoua M, Picard B, Soulat J, Monteils V. Clustering of sensory eating qualities of beef: Consistencies and differences within carcass, muscle, animal characteristics and rearing factors. Livestock Science. 2018;214:245-58.

[12] Gagaoua M, Terlouw EMC, Micol D, Hocquette JF, Moloney AP, Nuernberg K, et al. Sensory quality of meat from eight different types of cattle in relation with their biochemical characteristics. Journal of Integrative Agriculture. 2016;15:1550-63.

[13] Pogorzelska-Przybyłek P, Nogalski Z, Sobczuk-Szul M, Purwin C, Kubiak D. Carcass characteristics and meat quality of Holstein-Friesian $\times$ Hereford cattle of different sex categories and slaughter ages. Arch Anim Breed. 2018;61:253-61.

[14] Maltin CA, Balcerzak D, Tilley R, Delday M. Determinants of meat quality: tenderness. Proc Nutr Soc. 2003;62:337-47.

[15] Ellies-Oury M-P, Bonnet M, Gagaoua M, Mialon M-M, Durand D, Gruffat D, et al. Clustering of fatty acids composition, sensory quality and proteomic biomarkers of young Charolais bulls. In: Troy D, McDonnell C, Hinds L, Kerry J, editors. Proceedings of the $63^{\text {rd }}$ International Congress of Meat Science and Technology. First edition ed. Cork, Ireland: Wageningen Academic Publishers; 2017. p. 838-9.

[16] Picard B, Gagaoua M, Hollung K. Chapter 12 - Gene and Protein Expression as a Tool to Explain/Predict Meat (and Fish) Quality In: Purslow P, editor. New Aspects of Meat Quality : From Genes to Ethics. United Kingdom: Woodhead Publishing; 2017. p. 321-54. 
[17] Picard B, Gagaoua M. Chapter 11 - Proteomic Investigations of Beef Tenderness. In: Colgrave ML, editor. Proteomics in Food Science: from farm to fork. London: Academic 486 Press; 2017. p. 177-97.

487 [18] Picard B, Lebret B, Cassar-Malek I, Liaubet L, Berri C, Le Bihan-Duval E, et al. Recent advances in omic technologies for meat quality management. Meat science. 2015;109:18-26.

[19] Cao X-K, Cheng J, Huang Y-Z, Wang X-G, Ma Y-L, Peng S-J, et al. Growth Performance and Meat Quality Evaluations in Three-Way Cross Cattle Developed for the Tibetan Plateau and their Molecular Understanding by Integrative Omics Analysis. Journal of Agricultural and Food Chemistry. 2019;67:541-50.

493

494

495

496

497

498

499

500

501

502

503

504

505

506

507

508

509

510

511

512

513

514

515

516

517

518

519

520

521

[20] Gagaoua M, Bonnet M, De Koning L, Picard B. Reverse Phase Protein array for the quantification and validation of protein biomarkers of beef qualities: The case of meat color from Charolais breed. Meat science. 2018;145:308-19.

[21] Gagaoua M, Couvreur S, Le Bec G, Aminot G, Picard B. Associations among Protein Biomarkers and $\mathrm{pH}$ and Color Traits in Longissimus thoracis and Rectus abdominis Muscles in Protected Designation of Origin Maine-Anjou Cull Cows. J Agric Food Chem. 2017;65:3569-80.

[22] Gagaoua M, Bonnet M, Ellies-Oury MP, De Koning L, Picard B. Reverse phase protein arrays for the identification/validation of biomarkers of beef texture and their use for early classification of carcasses. Food Chemistry. 2018;250:245-52.

[23] Gagaoua M, Terlouw EM, Boudjellal A, Picard B. Coherent correlation networks among protein biomarkers of beef tenderness: What they reveal. J Proteomics. 2015;128:365-74.

[24] Ceciliani F, Lecchi C, Bazile J, Bonnet M. Proteomics Research in the Adipose Tissue. In: de Almeida AM, Eckersall D, Miller I, editors. Proteomics in Domestic Animals: from Farm to Systems Biology. Cham: Springer International Publishing; 2018. p. 233-54.

[25] Zhang Q, Lee HG, Han JA, Kim EB, Kang SK, Yin J, et al. Differentially expressed proteins during fat accumulation in bovine skeletal muscle. Meat science. 2010;86:814-20.

[26] Picard B, Gagaoua M, Al-Jammas M, De Koning L, Valais A, Bonnet M. Beef tenderness and intramuscular fat proteomic biomarkers: muscle type effect. PeerJ. 2018;6:e4891.

[27] Gagaoua M, Picard B, Monteils V. Associations among animal, carcass, muscle characteristics, and fresh meat color traits in Charolais cattle. Meat science. 2018;140:145-56.

[28] Troncale S, Barbet A, Coulibaly L, Henry E, He B, Barillot E, et al. NormaCurve: a SuperCurve-based method that simultaneously quantifies and normalizes reverse phase protein array data. PLoS One. 2012;7:e38686.

[29] Gagaoua M, Terlouw EM, Micol D, Boudjellal A, Hocquette JF, Picard B. Understanding Early Post-Mortem Biochemical Processes Underlying Meat Color and pH Decline in the Longissimus thoracis Muscle of Young Blond d'Aquitaine Bulls Using Protein Biomarkers. J Agric Food Chem. 2015;63:6799-809. 
[30] Brandstetter AM, Picard B, Geay Y. Muscle fibre characteristics in four muscles of growing bulls: I. Postnatal differentiation. Livestock Production Science. 1998;53:15-23.

524 [31] Oury MP, Dumont R, Jurie C, Hocquette JF, Picard B. Specific fibre composition and metabolism of the rectus abdominis muscle of bovine Charolais cattle. BMC Biochem. 2010;11:12.

527 [32] Enns DL, Tiidus PM. The Influence of Estrogen on Skeletal Muscle. Sports Medicine. 528 2010;40:41-58.

529 [33] Sauerwein H, Meyer HHD. Androgen and Estrogen Receptors in Bovine Skeletal 530 Muscle: Relation to Steroid-Induced Allometric Muscle Growth. Journal of Animal Science. $531 \quad 1989 ; 67: 206-12$.

[34] Xu Y, López M. Central regulation of energy metabolism by estrogens. Molecular Metabolism. 2018;15:104-15.

[35] Welle S, Tawil R, Thornton CA. Sex-Related Differences in Gene Expression in Human Skeletal Muscle. PLOS ONE. 2008;3:e1385. proteomics I. Which proteins in non-sexual organs. Journal of Proteomics. 2018;178:7-17.

[37] Miike K, Aoki M, Yamashita R, Takegawa Y, Saya H, Miike T, et al. Proteome profiling reveals gender differences in the composition of human serum. PROTEOMICS. 2010;10:2678-91.

[38] Rembold CM, Foster DB, Strauss JD, Wingard CJ, Van Eyk JE. cGMP-mediated phosphorylation of heat shock protein 20 may cause smooth muscle relaxation without myosin light chain dephosphorylation in swine carotid artery. The Journal of Physiology. 2000;524:865-78.

[39] Wang Y, Xu AM, Cooper GJS. Phosphorylation of P20 is associated with the actions of insulin in rat skeletal and smooth muscle. Biochemical Journal. 1999;344:971-6.

[40] Wyskida K, Franik G, Wikarek T, Owczarek A, Delroba A, Chudek J, et al. The levels of adipokines in relation to hormonal changes during the menstrual cycle in young, normalweight women. 2017;6:892.

550 [41] Li X, Zheng Y, Lu Z. PGK1 is a new member of the protein kinome. Cell cycle 551 (Georgetown, Tex). 2016;15:1803-4. - Molecular Mechanisms and Insulin Sensitivity. Frontiers in Endocrinology. 2014;5.

[43] Jeong J, Bong J, Kim GD, Joo ST, Lee HJ, Baik M. Transcriptome changes favoring intramuscular fat deposition in the longissimus muscle following castration of bulls. $\mathrm{J}$ Anim 556 Sci. 2013;91:4692-704.

[44] Gagaoua M, Terlouw EMC, Picard B. The study of protein biomarkers to understand the 558 biochemical processes underlying beef color development in young bulls. Meat Science. 2017;134:18-27. 
560 [45] Picard B, Gagaoua M, Micol D, Cassar-Malek I, Hocquette JF, Terlouw CE. Inverse 561 relationships between biomarkers and beef tenderness according to contractile and metabolic 562 properties of the muscle. J Agric Food Chem. 2014;62:9808-18.

563 [46] Lomiwes D, Farouk MM, Wiklund E, Young OA. Small heat shock proteins and their 564 role in meat tenderness: a review. Meat science. 2014;96:26-40.

565 [47] Charmpilas N, Kyriakakis E, Tavernarakis N. Small heat shock proteins in ageing and 566 age-related diseases. Cell Stress and Chaperones. 2017;22:481-92.

567 [48] Doran P, Gannon J, O'Connell K, Ohlendieck K. Aging skeletal muscle shows a drastic 568 increase in the small heat shock proteins $\alpha \mathrm{B}$-crystallin/HspB5 and cvHsp/HspB7. European 569 Journal of Cell Biology. 2007;86:629-40.

570 [49] Cowling BS, McGrath MJ, Nguyen M-A, Cottle DL, Kee AJ, Brown S, et al. 571 Identification of FHL1 as a regulator of skeletal muscle mass: implications for human 572 myopathy. The Journal of Cell Biology. 2008;183:1033-48.

573 [50] Morzel M, Chambon C, Hamelin M, Sante-Lhoutellier V, Sayd T, Monin G. Proteome 574 changes during pork meat ageing following use of two different pre-slaughter handling 575 procedures. Meat science. 2004;67:689-96.

576 [51] Lange S, Auerbach D, McLoughlin P, Perriard E, Schäfer BW, Perriard J-C, et al. 577 Subcellular targeting of metabolic enzymes to titin in heart muscle may be mediated by 578 DRAL/FHL-2. Journal of cell science. 2002;115:4925-36.

579 [52] Gagaoua M, Hafid K, Boudida Y, Becila S, Ouali A, Picard B, et al. Caspases and 580 Thrombin Activity Regulation by Specific Serpin Inhibitors in Bovine Skeletal Muscle. Appl 581 Biochem Biotechnol. 2015;177:279-303.

582 [53] Lee JY, Lori D, Wells DJ, Kemp PR. FHL1 activates myostatin signalling in skeletal 583 584 muscle and promotes atrophy. FEBS open bio. 2015;5:753-62. 


\section{Tables and Figures}

\section{Figure captions}

Figure 1. Interaction between muscle x gender for HSP20 protein.

Figure 2. Principal component analysis (PCA) depicting the relationships between the rearing practices of the 86 PDO Maine-Anjou cows identified following the procedure by Gagaoua et al. [8] with A) animal, rearing factors and carcass characteristics, and with B) the 20 protein biomarkers from the 5 muscles quantified by RPPA technique within the rearing factors. The projection of the individuals of haylage class (red), hay class (bleu) and grass class (green) are encircled in ellipses ( $\mathrm{x}, \mathrm{y}$-means $\pm \mathrm{x}, \mathrm{y}$-standard deviation (SD)) using the corresponding schematic colors. Furthermore, the barycenter of each muscle with the corresponding color are given.

Figure 3. Unsupervised hierarchical classification heatmap highlighting the differences in the quantified proteins in the five muscles and among the three rearing practices for cows. The proteins that were not affected by rearing practices or muscle type are shown by “*”. Colors correspond to the z-scores of the standardized values of protein fold-change between the muscles according to the 3 rearing factors.

Figure 4. Significant correlations $(P<0.05)$ between the 20 protein biomarkers and animal, rearing factors and carcass characteristics by muscle type. The negative correlations are given in red and the positive in green. The summary of the number of the correlations by muscle with the animal, rearing factors and carcass characteristics are given in a gradient-blue dependent color legend at the right down of the graph from 1 to 6 correlations in each muscle and with the same factor. For example, for TB muscle 6 significant correlations (intense bleu color) were found with fattening duration compared to animal activity where only one correlation was found (light bleu color). 
Table 1. List of the 20 protein biomarkers quantified using the Reverse Phase Protein Array (RPPA) technique. The suppliers and conditions for each primary antibody used in this study after western blotting validation are given as in Picard et al. [26] and Gagaoua et al. [11, 27].

\begin{tabular}{|c|c|c|c|}
\hline Protein biomarkers name (gene) & Uniprot ID & Monoclonal (Mo) or Polyclonal (Po) antibodies references & $\begin{array}{c}\text { Antibody } \\
\text { dilutions }\end{array}$ \\
\hline \multicolumn{4}{|l|}{ Metabolic enzymes } \\
\hline Malate dehydrogenase $(\mathrm{MDH} 1)$ & P40925 & Mo. anti-pig Rockland 100-601-145 & $1 / 1000$ \\
\hline$\beta$-enolase 3 (ENO3) & P13929 & Mo. anti-human Abnova Eno3 (M01), clone 5D1 & $1 / 30000$ \\
\hline Retinal dehydrogenase 1 (ALDHIAl) & P48644 & Po. anti-bovine Abcam ab23375 & $1 / 500$ \\
\hline Triosephosphate isomerase (TPII) & Q5E956 & Po. anti-human Novus NBP1-31470 & $1 / 50000$ \\
\hline Phosphoglycerate kinase $1(P G K 1)$ & Q3T0P6 & Po. anti-human Abcam ab90787 & $1 / 5000$ \\
\hline Fructose-bisphosphate aldolase $(A L D O A)$ & A6QLL8 & Po. anti-human Sigma AV48130 & $1 / 4000$ \\
\hline Glycogen phosphorylase $(P Y G B)$ & Q3B7M9 & Po. anti-human Santa Cruz SC-46347 & $1 / 250$ \\
\hline \multicolumn{4}{|l|}{ Heat shock proteins } \\
\hline$\alpha \mathrm{B}$-crystallin $(C R Y A B)$ & P02511 & Mo. anti-bovine Assay Designs SPA-222 & $1 / 1000$ \\
\hline Hsp20 (HSPBO) & 014558 & Mo. anti-human Santa Cruz HSP20-11:SC51955 & $1 / 500$ \\
\hline Hsp27 (HSPBI) & P04792 & Mo. anti-human Santa Cruz HSP27 (F-4):SC13132 & $1 / 3000$ \\
\hline Hsp40 (DNAJA1) & P31689 & Mo. anti-human Santa Cruz HSP40-4 (SPM251):SC-56400 & $1 / 250$ \\
\hline Hsp70-1A (HSPA1A) & Q27975 & Mo. anti-human RD Systems MAB1663 & $1 / 1000$ \\
\hline \multicolumn{4}{|l|}{ Oxidative proteins } \\
\hline Peroxiredoxin6 (PRDX6) & P30041 & Mo. anti-human Abnova PRDX6 (M01), clone 3A10-2A11 & $1 / 500$ \\
\hline \multicolumn{4}{|l|}{ Structural proteins } \\
\hline MLC-1F (MYL1) & P05976 & Po. anti-human Abnova MYL1 (A01) & $1 / 1000$ \\
\hline Myosin heavy chain-IIx $(M Y H I)$ & P12882 & Mo anti-bovine Biocytex 8F4 & $1 / 500$ \\
\hline Troponin T, slow skeletal muscle (TNNTI) & Q8MKH6 & Po. anti-human Sigma SAB2102501 & $1 / 4000$ \\
\hline Titin $(T T N)$ & Q8WZ42 & Mo. anti-human Novocastra NCL-TITIN & $1 / 100$ \\
\hline Tubulin alpha-4A chain (TUBA4A) & P81948 & Mo anti-human Sigma T6074 & $1 / 1000$ \\
\hline \multicolumn{4}{|l|}{ Cell death, protein binding and proteolysis } \\
\hline Tripartite motif protein 72 (Trim72) & E1BE77 & Po. anti-human Sigma SAB2102571 & $1 / 2000$ \\
\hline Four and a half LIM domains 1 (FHLI) & Q3T173 & Po. anti-human Sigma AV34378 & $1 / 5000$ \\
\hline
\end{tabular}


Table 2. Muscle, gender and muscle $x$ gender interaction effects on the 20 beef tenderness and intramuscular fat proteomic biomarkers.

\begin{tabular}{|c|c|c|c|c|c|c|c|c|c|c|c|}
\hline \multirow{2}{*}{ Proteins ${ }^{1}$} & \multirow{2}{*}{$\mathrm{G}$} & \multicolumn{5}{|c|}{ Muscle $(\mathrm{M})^{2}$} & \multicolumn{2}{|c|}{ Gender $(\mathrm{G})$} & \multicolumn{3}{|c|}{ P-values ${ }^{3}$} \\
\hline & & TB & ST & RA & $\mathrm{SM}$ & LT & Cows (C) & Steers (S) & $\mathrm{M}$ & $\mathrm{G}$ & $\mathrm{M} * \mathrm{G}$ \\
\hline $\begin{array}{c}\text { CRYAB } \\
\text { Sign. }^{4}\end{array}$ & $\begin{array}{l}\mathrm{C} \\
\mathrm{S}\end{array}$ & $\begin{array}{c}-0.15^{\mathrm{bc}} \\
-0.18^{\mathrm{b}} \\
\mathrm{ns}\end{array}$ & $\begin{array}{c}-0.62^{\mathrm{d}} \\
-0.67^{\mathrm{c}} \\
\mathrm{ns}\end{array}$ & $\begin{array}{l}1.03^{\mathrm{a}} \\
0.57^{\mathrm{a}} \\
* *\end{array}$ & $\begin{array}{c}-0.21^{\mathrm{c}} \\
-0.35^{\mathrm{b}} \\
\mathrm{ns}\end{array}$ & $\begin{array}{c}-0.02^{\mathrm{b}} \\
-0.06^{\mathrm{b}} \\
\mathrm{ns}\end{array}$ & 0.03 & -0.09 & $\begin{array}{l}* * * \\
* * *\end{array}$ & ns & ns \\
\hline $\begin{array}{r}\text { HSP20 } \\
\text { Sign. }\end{array}$ & $\begin{array}{l}\mathrm{C} \\
\mathrm{S}\end{array}$ & $\begin{array}{c}-0.23^{\mathrm{c}} \\
-0.34^{\mathrm{b}} \\
\mathrm{ns}\end{array}$ & $\begin{array}{c}-0.25^{\mathrm{c}} \\
-0.78^{\mathrm{b}} \\
* * *\end{array}$ & $\begin{array}{c}0.29^{\mathrm{a}} \\
0.16^{\mathrm{a}} \\
\mathrm{ns}\end{array}$ & $\begin{array}{c}0.01^{\mathrm{b}} \\
-0.46^{\mathrm{b}} \\
* * *\end{array}$ & $\begin{array}{c}0.17^{\mathrm{a}} \\
-0.42^{\mathrm{b}} \\
* * *\end{array}$ & $0.05^{\mathrm{a}}$ & $-0.33^{b}$ & $\begin{array}{l}* * * \\
* *\end{array}$ & $* * *$ & $* *$ \\
\hline $\begin{array}{r}H S P 27 \\
\text { Sign. }\end{array}$ & $\begin{array}{l}\mathrm{C} \\
\mathrm{S}\end{array}$ & $\begin{array}{c}-0.06^{\mathrm{b}} \\
-0.19^{\mathrm{b}} \\
\mathrm{ns}\end{array}$ & $\begin{array}{c}-0.08^{\mathrm{b}} \\
-0.27^{\mathrm{b}} \\
*\end{array}$ & $\begin{array}{l}0.61^{\mathrm{a}} \\
0.27^{\mathrm{a}} \\
\quad *\end{array}$ & $\begin{array}{c}-0.44^{\mathrm{c}} \\
-0.65^{\mathrm{c}} \\
*\end{array}$ & $\begin{array}{c}-0.04^{\mathrm{b}} \\
-0.05^{\mathrm{b}} \\
\mathrm{ns}\end{array}$ & 0.03 & -0.14 & $\begin{array}{l}* * * \\
* * *\end{array}$ & $\mathrm{~ns}$ & ns \\
\hline $\begin{array}{c}\text { HSP70-1A } \\
\text { Sign. }\end{array}$ & $\begin{array}{l}\mathrm{C} \\
\mathrm{S}\end{array}$ & $\begin{array}{c}-0.20^{\mathrm{c}} \\
-0.02 \\
\mathrm{~ns}\end{array}$ & $\begin{array}{c}-0.36^{\mathrm{c}} \\
-0.17 \\
\mathrm{~ns}\end{array}$ & $\begin{array}{c}0.28^{\mathrm{a}} \\
0.17 \\
\mathrm{~ns}\end{array}$ & $\begin{array}{c}0.17^{\mathrm{ab}} \\
0.01 \\
\mathrm{~ns}\end{array}$ & $\begin{array}{c}0.08^{\mathrm{b}} \\
0.15 \\
\mathrm{~ns}\end{array}$ & -0.02 & 0.05 & $\begin{array}{c}* * * \\
\mathrm{~ns}\end{array}$ & ns & ns \\
\hline $\begin{array}{c}H S P 40 \\
\text { Sign. } \\
\end{array}$ & $\begin{array}{l}\mathrm{C} \\
\mathrm{S}\end{array}$ & $\begin{array}{c}-0.11 \\
-0.03 \\
\mathrm{~ns}\end{array}$ & $\begin{array}{l}0.02 \\
0.30 \\
*\end{array}$ & $\begin{array}{c}-0.05 \\
0.09 \\
\text { ns }\end{array}$ & $\begin{array}{c}0.06 \\
0.12 \\
\mathrm{~ns}\end{array}$ & $\begin{array}{c}-0.11 \\
-0.01 \\
n s\end{array}$ & -0.05 & 0.03 & $\begin{array}{l}\mathrm{ns} \\
\mathrm{ns}\end{array}$ & ns & ns \\
\hline $\begin{array}{c}\text { FHL1 } \\
\text { Sign. }\end{array}$ & $\begin{array}{l}\mathrm{C} \\
\mathrm{S}\end{array}$ & $\begin{array}{c}0.12 \\
0.13 \\
\mathrm{~ns}\end{array}$ & $\begin{array}{c}-0.16 \\
0.03 \\
n s\end{array}$ & $\begin{array}{c}0.04 \\
0.14 \\
\mathrm{~ns}\end{array}$ & $\begin{array}{c}-0.03 \\
-0.05 \\
\mathrm{~ns}\end{array}$ & $\begin{array}{c}0.01 \\
0.13 \\
\mathrm{~ns}\end{array}$ & -0.01 & 0.07 & $\begin{array}{l}\mathrm{ns} \\
\mathrm{ns}\end{array}$ & ns & ns \\
\hline $\begin{array}{r}\text { TRIM72 } \\
\text { Sign. }\end{array}$ & $\begin{array}{l}\mathrm{C} \\
\mathrm{S}\end{array}$ & $\begin{array}{c}0.41^{\mathrm{a}} \\
0.34^{\mathrm{a}} \\
\mathrm{ns}\end{array}$ & $\begin{array}{c}-0.08^{\mathrm{b}} \\
-0.20^{\mathrm{c}} \\
*\end{array}$ & $\begin{array}{c}0.01^{b} \\
-0.04^{b c} \\
n s\end{array}$ & $\begin{array}{c}-0.11^{\mathrm{b}} \\
-0.07^{\mathrm{bc}} \\
\mathrm{ns}\end{array}$ & $\begin{array}{l}0.32^{\mathrm{a}} \\
0.11^{\mathrm{b}} \\
* *\end{array}$ & 0.13 & 0.04 & $\begin{array}{l}* * * \\
* * *\end{array}$ & ns & $\mathrm{ns}$ \\
\hline $\begin{array}{r}\text { PRDX6 } \\
\text { Sign. } \\
\end{array}$ & $\begin{array}{l}\mathrm{C} \\
\mathrm{S}\end{array}$ & $\begin{array}{c}0.16^{\mathrm{a}} \\
0.37^{\mathrm{a}} \\
\mathrm{ns}\end{array}$ & $\begin{array}{c}0.12^{\mathrm{ab}} \\
0.35^{\mathrm{a}} \\
\mathrm{ns}\end{array}$ & $\begin{array}{c}-0.03^{\mathrm{b}} \\
0.33^{\mathrm{a}} \\
* *\end{array}$ & $\begin{array}{c}0.26^{\mathrm{a}} \\
0.38^{\mathrm{a}} \\
\mathrm{ns}\end{array}$ & $\begin{array}{c}-0.33^{\mathrm{c}} \\
-0.07^{\mathrm{b}} \\
*\end{array}$ & $0.00^{\mathrm{b}}$ & $0.23^{\mathrm{a}}$ & $\begin{array}{c}* * * \\
*\end{array}$ & $* *$ & $\mathrm{~ns}$ \\
\hline $\begin{array}{c}\text { MDH1 } \\
\text { Sign. }\end{array}$ & $\begin{array}{l}\mathrm{C} \\
\mathrm{S}\end{array}$ & $\begin{array}{c}0.09 \\
-0.01 \\
\text { ns }\end{array}$ & $\begin{array}{c}0.04 \\
-0.08 \\
\mathrm{~ns}\end{array}$ & $\begin{array}{c}0.01 \\
-0.15 \\
\text { ns }\end{array}$ & $\begin{array}{c}-0.11 \\
-0.14 \\
\text { ns }\end{array}$ & $\begin{array}{c}0.07 \\
-0.09 \\
n s\end{array}$ & $0.04^{\mathrm{a}}$ & $-0.09^{b}$ & $\begin{array}{l}\text { ns } \\
\text { ns }\end{array}$ & $*$ & ns \\
\hline $\begin{array}{c}P Y G B \\
\text { Sign. }\end{array}$ & $\begin{array}{l}\mathrm{C} \\
\mathrm{S}\end{array}$ & $\begin{array}{c}0.08 \\
0.06 \\
\mathrm{~ns}\end{array}$ & $\begin{array}{c}0.11 \\
0.08 \\
\mathrm{~ns}\end{array}$ & $\begin{array}{c}-0.02 \\
0.07 \\
n s\end{array}$ & $\begin{array}{c}0.05 \\
0.18 \\
\text { ns }\end{array}$ & $\begin{array}{c}0.01 \\
-0.08 \\
n s\end{array}$ & 0.04 & 0.07 & $\begin{array}{l}\text { ns } \\
\text { ns }\end{array}$ & ns & ns \\
\hline $\begin{array}{c}P G K 1 \\
\text { Sign. }\end{array}$ & $\begin{array}{l}\mathrm{C} \\
\mathrm{S}\end{array}$ & $\begin{array}{l}0.11^{\mathrm{b}} \\
0.33^{\mathrm{b}} \\
\quad *\end{array}$ & $\begin{array}{c}0.39^{\mathrm{a}} \\
0.83^{\mathrm{a}} \\
* * *\end{array}$ & $\begin{array}{c}-0.95^{\mathrm{c}} \\
-0.52^{\mathrm{c}} \\
*\end{array}$ & $\begin{array}{c}0.35^{\mathrm{a}} \\
0.59^{\mathrm{ab}} \\
*\end{array}$ & $\begin{array}{l}0.11^{\mathrm{b}} \\
0.39^{\mathrm{b}} \\
*\end{array}$ & $-0.06^{\mathrm{b}}$ & $0.30^{\mathrm{a}}$ & $\begin{array}{l}* * * \\
* * *\end{array}$ & $* * *$ & ns \\
\hline $\begin{array}{c}\text { ALDOA } \\
\text { Sign. }\end{array}$ & $\begin{array}{l}\mathrm{C} \\
\mathrm{S}\end{array}$ & $\begin{array}{c}-0.04^{\mathrm{b}} \\
-0.03^{\mathrm{ab}} \\
\mathrm{ns}\end{array}$ & $\begin{array}{c}0.26^{\mathrm{a}} \\
0.25^{\mathrm{a}} \\
\mathrm{ns}\end{array}$ & $\begin{array}{c}-0.24^{\mathrm{c}} \\
-0.25^{\mathrm{b}} \\
\mathrm{ns}\end{array}$ & $\begin{array}{c}0.16^{\mathrm{a}} \\
0.02^{\mathrm{ab}} \\
\mathrm{ns}\end{array}$ & $\begin{array}{c}-0.02^{\mathrm{b}} \\
-0.27^{\mathrm{b}} \\
*\end{array}$ & $0.04^{\mathrm{a}}$ & $-0.11^{b}$ & $\begin{array}{l}* * * \\
* *\end{array}$ & $* *$ & ns \\
\hline $\begin{array}{c}\text { ALDHIAl } \\
\text { Sign. }\end{array}$ & $\begin{array}{l}\mathrm{C} \\
\mathrm{S}\end{array}$ & $\begin{array}{c}-0.16^{\mathrm{bc}} \\
-0.06^{\mathrm{b}} \\
\mathrm{ns}\end{array}$ & $\begin{array}{c}-0.07^{\mathrm{b}} \\
0.11^{\mathrm{b}} \\
\mathrm{ns}\end{array}$ & $\begin{array}{c}0.73^{\mathrm{a}} \\
0.67^{\mathrm{a}} \\
\mathrm{ns}\end{array}$ & $\begin{array}{c}-0.28^{\mathrm{c}} \\
-0.03^{\mathrm{b}} \\
*\end{array}$ & $\begin{array}{c}-0.15^{\mathrm{bc}} \\
0.05^{\mathrm{b}} \\
\mathrm{ns}\end{array}$ & 0.00 & 0.14 & $\begin{array}{l}* * * \\
* * *\end{array}$ & ns & ns \\
\hline $\begin{array}{c}\text { ENO3 } \\
\text { Sign. }\end{array}$ & $\begin{array}{l}\mathrm{C} \\
\mathrm{S}\end{array}$ & $\begin{array}{c}0.22^{\mathrm{bc}} \\
0.17^{\mathrm{b}} \\
\mathrm{ns}\end{array}$ & $\begin{array}{l}0.58^{\mathrm{a}} \\
0.76^{\mathrm{a}} \\
\quad *\end{array}$ & $\begin{array}{c}-1.22^{\mathrm{d}} \\
-0.70^{\mathrm{c}} \\
* *\end{array}$ & $\begin{array}{c}0.33^{\mathrm{b}} \\
0.31^{\mathrm{b}} \\
\mathrm{ns}\end{array}$ & $\begin{array}{c}0.10^{\mathrm{c}} \\
0.27^{\mathrm{b}} \\
\mathrm{ns}\end{array}$ & -0.03 & 0.14 & $\begin{array}{l}* * * \\
* * *\end{array}$ & ns & ns \\
\hline $\begin{array}{l}\text { TPII } \\
\text { Sign. }\end{array}$ & $\begin{array}{l}\mathrm{C} \\
\mathrm{S}\end{array}$ & $\begin{array}{c}0.04^{\mathrm{c}} \\
0.11^{\mathrm{b}} \\
\mathrm{ns}\end{array}$ & $\begin{array}{c}0.55^{\mathrm{a}} \\
0.86^{\mathrm{a}} \\
* * \\
\end{array}$ & $\begin{array}{c}-1.02^{\mathrm{d}} \\
-0.56^{\mathrm{c}} \\
*\end{array}$ & $\begin{array}{c}0.31^{\mathrm{b}} \\
0.45^{\mathrm{b}} \\
\mathrm{ns} \\
\end{array}$ & $\begin{array}{c}-0.03^{\mathrm{c}} \\
0.24^{\mathrm{b}} \\
\mathrm{ns}\end{array}$ & $-0.08^{b}$ & $0.18^{\mathrm{a}}$ & $\begin{array}{l}* * * \\
* * *\end{array}$ & $*$ & ns \\
\hline
\end{tabular}

\footnotetext{
${ }^{1}$ Least-square means in the same row with different superscript letters are significantly different $(P<0.05)$.

${ }^{2}$ Muscle abbreviation:

TB: Triceps brachii; ST: Semitendinosus ; RA: Rectus abdominis ; SM: Semimembranosus ; LT: Longissimus thoracis

${ }^{3}$ Significances: ns: not significant; $* P<0.05 ; * * P<0.01 ; * * * P<0.001$

${ }^{4}$ Gender effect significance on the proteins by muscle.
} 
Table 2. Continued

\begin{tabular}{|c|c|c|c|c|c|c|c|c|c|c|c|}
\hline \multirow{2}{*}{ Proteins $^{1}$} & \multirow{2}{*}{ G } & \multicolumn{5}{|c|}{ Muscle $(\mathrm{M})^{2}$} & \multicolumn{2}{|c|}{ Gender (G) } & \multicolumn{3}{|c|}{ P-values ${ }^{3}$} \\
\hline & & TB & ST & RA & SM & $\mathrm{LT}$ & Cows $(\mathrm{C})$ & Steers (S) & $\mathrm{M}$ & $\mathrm{G}$ & $\mathrm{M}^{*} \mathrm{G}$ \\
\hline \multirow[b]{2}{*}{$T T N$} & $\mathrm{C}$ & $0.30^{\mathrm{a}}$ & $-0.33^{\mathrm{c}}$ & $-0.05^{b}$ & $-0.31^{\mathrm{c}}$ & $0.34^{\mathrm{a}}$ & \multirow{3}{*}{-0.01} & \multirow{3}{*}{0.04} & $* * *$ & \multirow{3}{*}{ ns } & \multirow{3}{*}{$\mathrm{ns}$} \\
\hline & $\mathrm{S}$ & $0.34^{\mathrm{a}}$ & $-0.32^{b}$ & $-0.20^{\mathrm{b}}$ & $-0.05^{b}$ & $0.22^{\mathrm{a}}$ & & & $* *$ & & \\
\hline Sign. & & $\mathrm{ns}$ & ns & ns & ns & $\mathrm{ns}$ & & & & & \\
\hline \multirow{2}{*}{$M H C-I I X$} & $\mathrm{C}$ & $0.27^{\mathrm{b}}$ & $0.75^{\mathrm{a}}$ & $-0.91^{\mathrm{d}}$ & $0.06^{\mathrm{b}}$ & $-0.21^{\mathrm{c}}$ & \multirow{3}{*}{$0.03^{\mathrm{a}}$} & \multirow{3}{*}{$-0.24^{b}$} & $* * *$ & \multirow{3}{*}{$*$} & \multirow{3}{*}{ ns } \\
\hline & $\mathrm{S}$ & $0.08^{\mathrm{a}}$ & $0.30^{\mathrm{a}}$ & $-0.83^{b}$ & $-0.07^{\mathrm{a}}$ & $-0.54^{b}$ & & & $* * *$ & & \\
\hline Sign. & & ns & $* *$ & ns & ns & $\mathrm{ns}$ & & & & & \\
\hline \multirow{2}{*}{$M L C 1 F$} & $\mathrm{C}$ & $0.26^{\mathrm{ab}}$ & $0.39^{\mathrm{a}}$ & $-0.56^{\mathrm{c}}$ & $0.08^{\mathrm{b}}$ & $0.09^{\mathrm{b}}$ & \multirow{3}{*}{0.06} & \multirow{3}{*}{-0.02} & $* * *$ & \multirow{3}{*}{ ns } & \multirow{3}{*}{ ns } \\
\hline & $\mathrm{S}$ & $0.20^{\mathrm{a}}$ & $0.24^{\mathrm{a}}$ & $-0.54^{\mathrm{b}}$ & $0.09^{\mathrm{a}}$ & $0.09^{a}$ & & & $* * *$ & & \\
\hline Sign. & & ns & ns & ns & ns & $\mathrm{ns}$ & & & & & \\
\hline \multirow[b]{2}{*}{ TNNT1 } & $\mathrm{C}$ & $0.09^{\mathrm{b}}$ & $-0.97^{\mathrm{d}}$ & $0.88^{\mathrm{a}}$ & $-0.13^{\mathrm{c}}$ & $0.08^{\mathrm{b}}$ & \multirow{3}{*}{$-0.02^{b}$} & \multirow{3}{*}{$0.19^{\mathrm{a}}$} & $* * *$ & \multirow{3}{*}{$*$} & \multirow{3}{*}{ ns } \\
\hline & $\mathrm{S}$ & $0.27^{\mathrm{b}}$ & $-0.76^{c}$ & $0.87^{\mathrm{a}}$ & $0.05^{\mathrm{b}}$ & $0.28^{\mathrm{b}}$ & & & $* * *$ & & \\
\hline Sign. & & ns & $\mathrm{ns}$ & $\mathrm{ns}$ & $\mathrm{ns}$ & $*$ & & & & & \\
\hline \multirow{2}{*}{$\alpha$-Tubulin } & $\mathrm{C}$ & $0.05^{\mathrm{a}}$ & $-0.03^{\mathrm{ab}}$ & $0.10^{\mathrm{a}}$ & $-0.02^{\mathrm{ab}}$ & $-0.13^{b}$ & \multirow{3}{*}{0.01} & \multirow{3}{*}{-0.08} & $* *$ & \multirow{3}{*}{ ns } & \multirow{3}{*}{ ns } \\
\hline & $\mathrm{S}$ & 0.05 & 0.03 & -0.01 & -0.16 & -0.27 & & & ns & & \\
\hline Sign. & & $\mathrm{ns}$ & $\mathrm{ns}$ & $\mathrm{ns}$ & $*$ & ns & & & & & \\
\hline
\end{tabular}

${ }^{1}$ Least-square means in the same row with different superscript letters are significantly different $(P<0.05)$.

${ }^{2}$ Muscle abbreviation:

TB: Triceps brachii; ST: Semitendinosus ; RA: Rectus abdominis ; SM: Semimembranosus ; LT: Longissimus thoracis

${ }^{3}$ Significances: ns: not significant; $* P<0.05$; ** $P<0.01$; *** $P<0.001$

${ }^{4}$ Gender effect significance on the proteins by muscle. 
Table 3. Variance analyses of the rearing practices and muscle $\mathrm{x}$ rearing practices interaction effects on the 20 beef tenderness and intramuscular fat proteomic biomarkers for cows and steers.

\begin{tabular}{|c|c|c|c|}
\hline \multirow[b]{2}{*}{ Proteins $^{1}$} & \multirow[b]{2}{*}{ Gender } & \multicolumn{2}{|r|}{ Effects $^{3}$} \\
\hline & & $\begin{array}{l}\text { Rearing } \\
\text { practices }\end{array}$ & $\begin{array}{c}\text { Rearing practices } \mathrm{x} \\
\text { muscle }\end{array}$ \\
\hline \multirow{2}{*}{$C R Y A B$} & Cows $(\mathrm{C})$ & ns & ns \\
\hline & Steers $(\mathrm{S})^{2}$ & $\mathrm{~ns}$ & ns \\
\hline \multirow{2}{*}{ HSP2O } & $\mathrm{C}$ & 0.073 & ns \\
\hline & S & ns & ns \\
\hline \multirow{2}{*}{$H S P 27$} & $\mathrm{C}$ & $\mathrm{ns}$ & $\mathrm{ns}$ \\
\hline & S & ns & ns \\
\hline \multirow{2}{*}{$H S P 70-1 A$} & $\mathrm{C}$ & $\mathrm{ns}$ & ns \\
\hline & S & ns & 0.093 \\
\hline \multirow{2}{*}{ HSP40 } & $\mathrm{C}$ & $\mathrm{ns}$ & ns \\
\hline & $\mathrm{S}$ & ns & ns \\
\hline \multirow{2}{*}{ FHLI } & $\mathrm{C}$ & $\mathrm{ns}$ & ns \\
\hline & $\mathrm{S}$ & ns & ns \\
\hline \multirow{2}{*}{ TRIM72 } & $\mathrm{C}$ & $\mathrm{ns}$ & $\mathrm{ns}$ \\
\hline & S & ns & ns \\
\hline \multirow{2}{*}{ PRDX6 } & $\mathrm{C}$ & 0.019 & ns \\
\hline & $\mathrm{S}$ & $\mathrm{ns}$ & ns \\
\hline \multirow{2}{*}{$M D H 1$} & $\mathrm{C}$ & 0.088 & ns \\
\hline & S & ns & ns \\
\hline \multirow{2}{*}{$P Y G B$} & $\mathrm{C}$ & $\mathrm{ns}$ & 0.087 \\
\hline & $\mathrm{S}$ & ns & ns \\
\hline \multirow{2}{*}{$P G K 1$} & $\mathrm{C}$ & 0.038 & ns \\
\hline & S & ns & ns \\
\hline \multirow{2}{*}{$A L D O A$} & $\mathrm{C}$ & 0.035 & ns \\
\hline & $\mathrm{S}$ & 0.098 & ns \\
\hline \multirow{2}{*}{$A L D H 1 A 1$} & $\mathrm{C}$ & $\mathrm{ns}$ & $\mathrm{ns}$ \\
\hline & $S$ & 0.056 & ns \\
\hline \multirow{2}{*}{ ENO3 } & $\mathrm{C}$ & 0.056 & ns \\
\hline & $\mathrm{S}$ & ns & ns \\
\hline \multirow{2}{*}{ TPII } & $\mathrm{C}$ & $\mathrm{ns}$ & ns \\
\hline & $\mathrm{S}$ & ns & ns \\
\hline \multirow{2}{*}{$T T N$} & $\mathrm{C}$ & ns & ns \\
\hline & $\mathrm{S}$ & $\mathrm{ns}$ & ns \\
\hline \multirow{2}{*}{ MHC-IIX } & $\mathrm{C}$ & $\mathrm{ns}$ & ns \\
\hline & $\mathrm{S}$ & $\mathrm{ns}$ & ns \\
\hline \multirow{2}{*}{$M L C 1 F$} & $\mathrm{C}$ & $\mathrm{ns}$ & ns \\
\hline & $\mathrm{S}$ & ns & ns \\
\hline \multirow{2}{*}{$T N N T 1$} & $\mathrm{C}$ & ns & ns \\
\hline & $\mathrm{S}$ & $\mathrm{ns}$ & ns \\
\hline \multirow{2}{*}{$\alpha$-Tubulin } & $\mathrm{C}$ & ns & ns \\
\hline & $\mathrm{S}$ & $\mathrm{ns}$ & ns \\
\hline
\end{tabular}

${ }^{1}$ Least-square means in the same row with different superscript letters are significantly different $(P<0.05)$.

${ }^{2}$ Only two rearing factors were identified for steers (Grass class (n $=5)$ and Haylage class $(\mathrm{n}=10))$.

${ }^{3}$ ns: not significant $(P>0.1)$. 
Table 4. Differences in animal, rearing factors and carcass characteristics among the three identified rearing practices.

\begin{tabular}{lrrrc}
\hline Variables & $\begin{array}{c}\text { Grass class } \\
(\mathrm{n}=24)\end{array}$ & $\begin{array}{c}\text { Haylage class } \\
(\mathrm{n}=21)\end{array}$ & $\begin{array}{c}\text { Hay class } \\
(\mathrm{n}=41)\end{array}$ & P-values $^{1}$ \\
\hline Animal activity, \% & $78.79^{\mathrm{a}}$ & $2.81^{\mathrm{b}}$ & $5.29^{\mathrm{b}}$ & $* * *$ \\
Grass, \% & $19.10^{\mathrm{a}}$ & $0.80^{\mathrm{b}}$ & $0.53^{\mathrm{b}}$ & $* * *$ \\
Haylage, \% & $59.71^{\mathrm{b}}$ & $81.99^{\mathrm{a}}$ & $4.70^{\mathrm{c}}$ & $* * *$ \\
Hay, \% & $21.15^{\mathrm{b}}$ & $17.21^{\mathrm{b}}$ & $94.77^{\mathrm{a}}$ & $* * *$ \\
Total concentrate, kg & 857 & 741 & 788 & $\mathrm{~ns}$ \\
Fattening duration, days & $120.3^{\mathrm{a}}$ & $100.3^{\mathrm{b}}$ & $99.5^{\mathrm{b}}$ & $*$ \\
Age, months & $64.50^{\mathrm{b}}$ & $65.19^{\mathrm{b}}$ & $71.22^{\mathrm{a}}$ & $\mathrm{t}$ \\
Carcass weight, kg & $461.33^{\mathrm{a}}$ & $434.10^{\mathrm{b}}$ & $462.24^{\mathrm{a}}$ & $*$ \\
Conformation score & $3.54^{\mathrm{b}}$ & $4.10^{\mathrm{a}}$ & $3.85^{\mathrm{ab}}$ & $\mathrm{t}$ \\
\hline
\end{tabular}

${ }^{1}$ Significances: ns: not significant; $\mathrm{t} P<0.1 ; * P<0.05 ; * * * P<0.001$ 


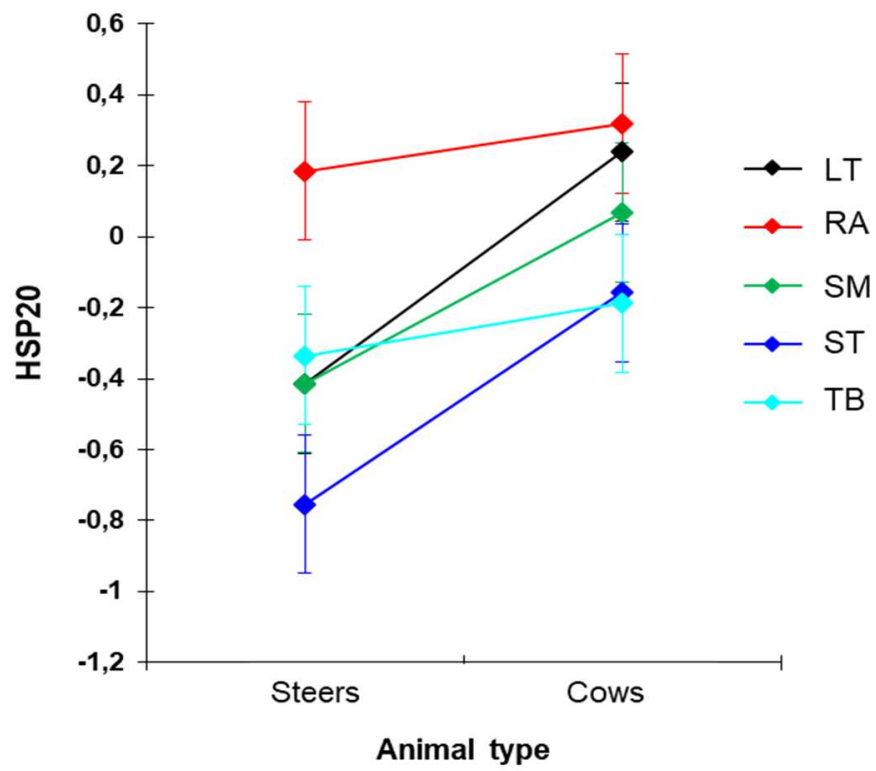

Figure 1. 

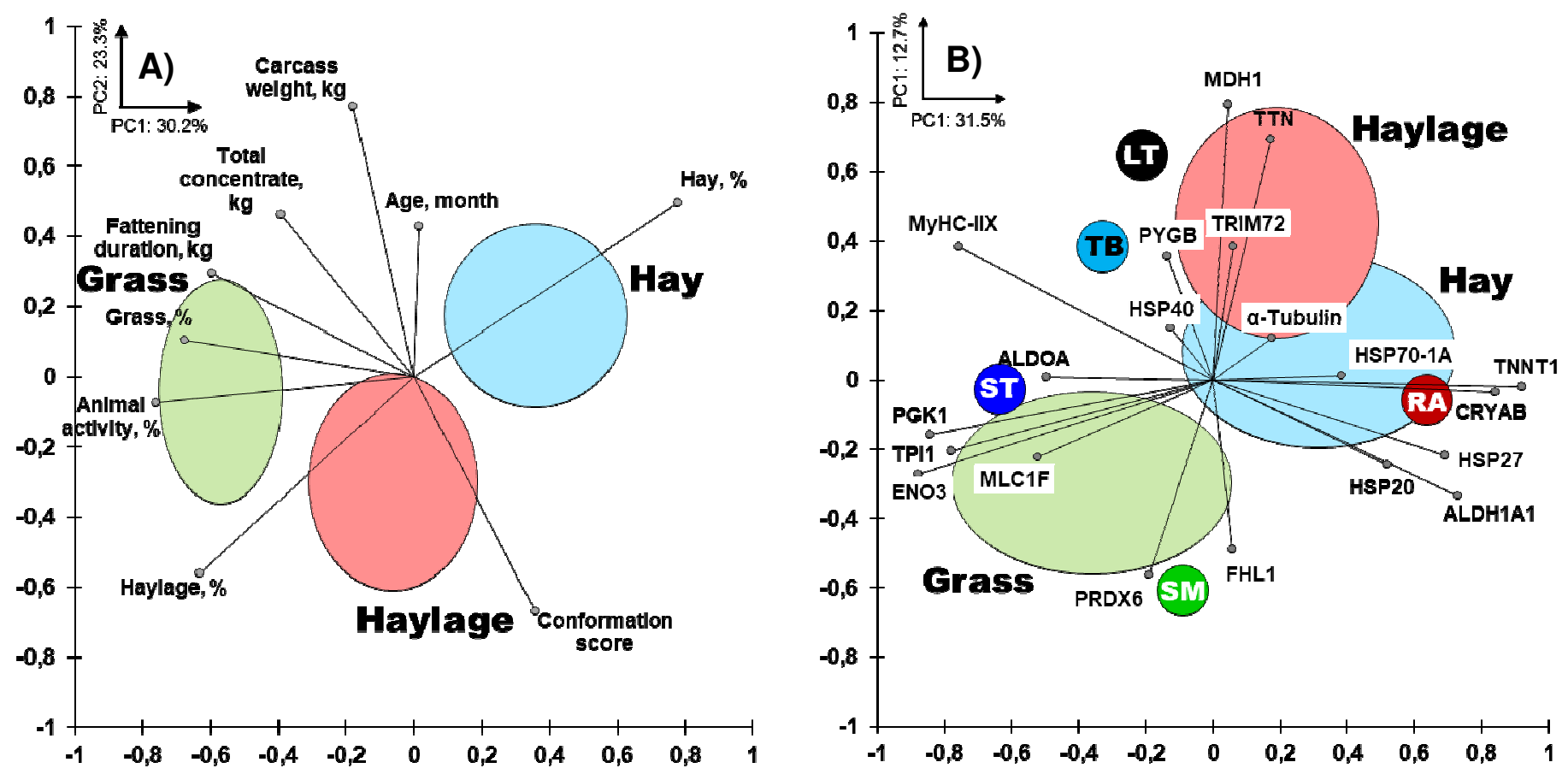

Figure 2. 


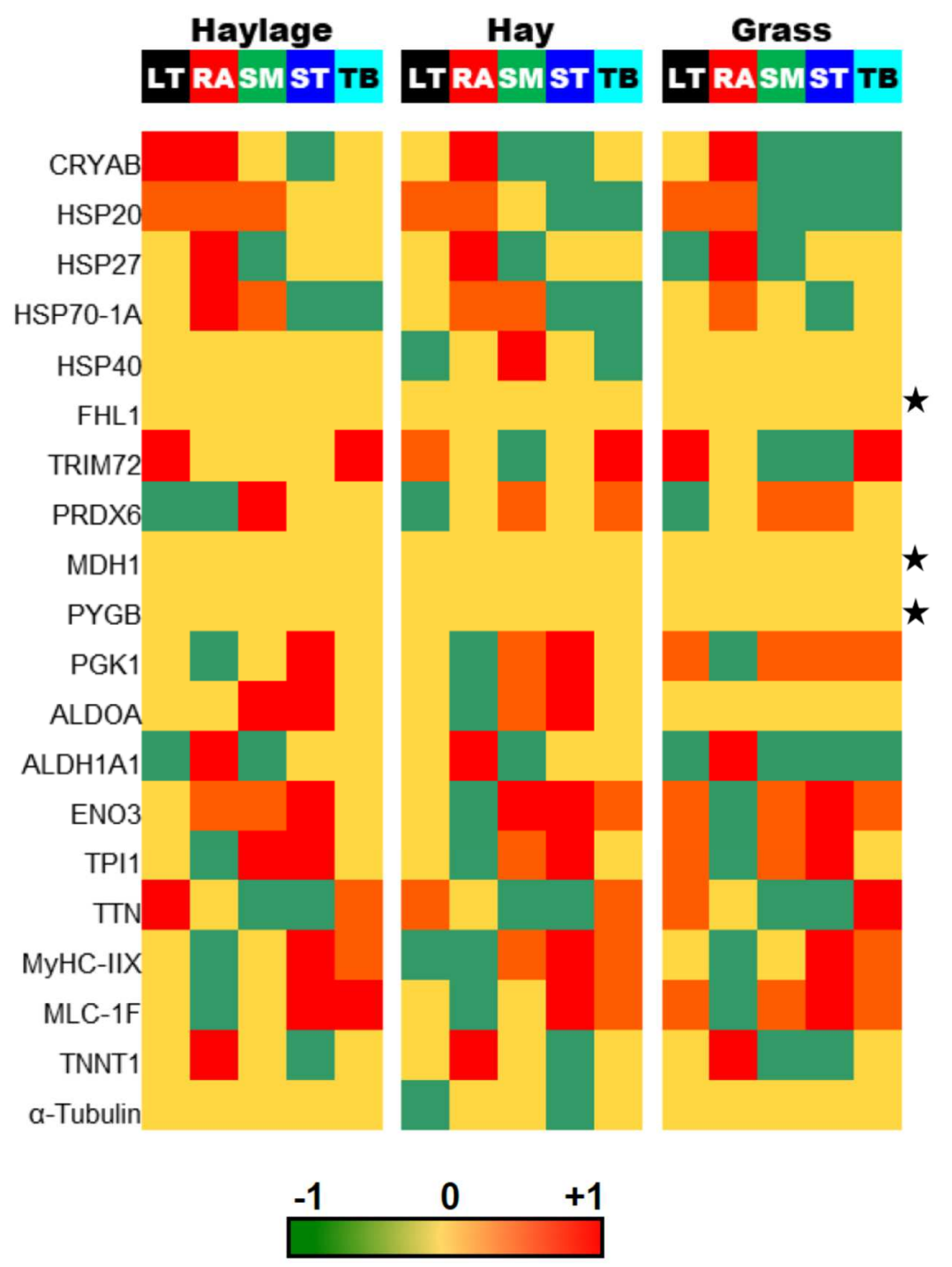

Figure 3. 


\begin{tabular}{|c|c|c|c|}
\hline & \multicolumn{3}{|c|}{ Animal activity, \% } \\
\hline & \begin{tabular}{|l|l|} 
LT & RA \\
\end{tabular} & \begin{tabular}{|l|l|} 
SM & ST \\
\end{tabular} & TB \\
\hline \multicolumn{4}{|l|}{ CRYAB } \\
\hline \multicolumn{4}{|l|}{ HSP2O } \\
\hline \multicolumn{4}{|l|}{ HSP27 } \\
\hline \multicolumn{4}{|l|}{ HSP70-1A } \\
\hline \multicolumn{4}{|l|}{ HSP4O } \\
\hline \multicolumn{4}{|l|}{$F H L 1$} \\
\hline \multicolumn{4}{|l|}{ TRIM72 } \\
\hline \multicolumn{4}{|l|}{ PRDX6 } \\
\hline \multicolumn{4}{|c|}{ 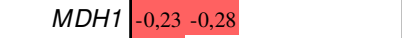 } \\
\hline \multicolumn{4}{|c|}{ PYGB $-0,25$} \\
\hline \multicolumn{4}{|l|}{$P G K 1$} \\
\hline \multicolumn{4}{|l|}{$A L D O A$} \\
\hline \multicolumn{4}{|l|}{$A L D H 1 A 1$} \\
\hline \multicolumn{4}{|l|}{ ENO3 } \\
\hline \multicolumn{4}{|c|}{$\begin{array}{ll}\text { TPI1 } & 0,28 \\
\end{array}$} \\
\hline \multicolumn{4}{|l|}{ TTN } \\
\hline \multirow{2}{*}{\multicolumn{4}{|c|}{$\begin{array}{r}M y H C-I I X \\
M I C-1 F\end{array}$}} \\
\hline \multirow{2}{*}{\multicolumn{4}{|c|}{$\begin{array}{r}M L C-1 F \\
T N N T 1\end{array}$}} \\
\hline & & & \\
\hline \multicolumn{4}{|l|}{$\alpha$-Tubulin } \\
\hline & & & \\
\hline
\end{tabular}

\begin{tabular}{|c|c|c|c|c|c|}
\hline & \multicolumn{5}{|c|}{ EUROP conformation } \\
\hline & LT & RA & SM & ST & TB \\
\hline \multicolumn{6}{|l|}{ CRYAB } \\
\hline \multicolumn{6}{|l|}{ HSP2O } \\
\hline \multicolumn{6}{|c|}{\begin{tabular}{l|l} 
HSP27 & 0,22
\end{tabular}} \\
\hline \multicolumn{6}{|l|}{ HSP70-1A } \\
\hline \multicolumn{6}{|l|}{ HSP 40} \\
\hline \multicolumn{6}{|l|}{$F H L 1$} \\
\hline \multicolumn{6}{|l|}{ TRIM72 } \\
\hline \multicolumn{6}{|l|}{ PRDX6 } \\
\hline \multicolumn{6}{|l|}{$M D H 1$} \\
\hline \multicolumn{6}{|l|}{ PYGB } \\
\hline \multicolumn{6}{|l|}{ PGK1 } \\
\hline \multicolumn{6}{|l|}{$A L D O A$} \\
\hline \multicolumn{6}{|l|}{$A L D H 1 A 1$} \\
\hline \multicolumn{6}{|l|}{ ENO3 } \\
\hline \multicolumn{6}{|l|}{$T P / 1$} \\
\hline \multicolumn{6}{|l|}{$T T N$} \\
\hline \multicolumn{6}{|l|}{$M y H C-I I X$} \\
\hline \multicolumn{6}{|l|}{$M L C-1 F$} \\
\hline \multicolumn{6}{|l|}{$T N N T 1$} \\
\hline$\alpha$-Tubulin & & & & & \\
\hline & & & & & \\
\hline
\end{tabular}

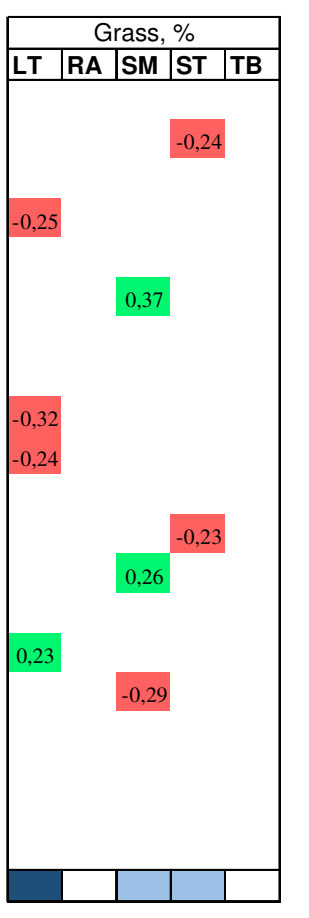

Age at slaugher, months \begin{tabular}{|l|l|l|l|l|}
\hline LT & RA & SM & ST & TB \\
\hline
\end{tabular}

$\begin{array}{lllll}0,44 & 0,23 & 0,31 & 0,22 & 0,23\end{array}$

$\begin{array}{lllll}0,44 & 0,23 & 0,31 & 0,22 & 0,23\end{array}$

0,33

0,27

$0,26 \quad 0,32$

0,28
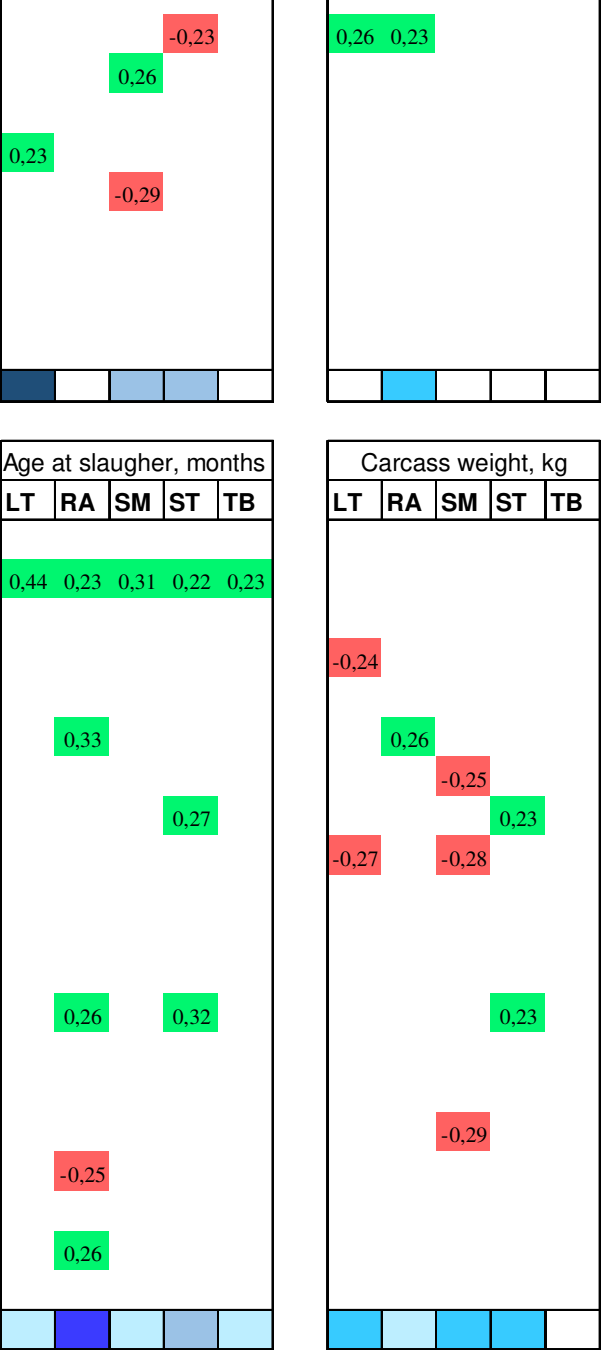

Figure 4.

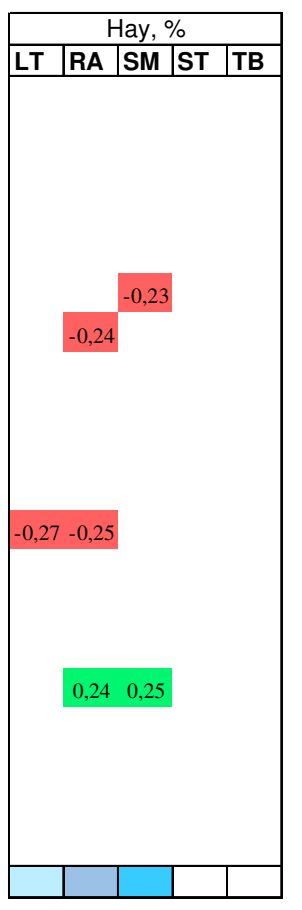

Fattening duration, days \begin{tabular}{|l|l|l|l|l|}
\hline LT & RA & SM & ST & TB \\
\hline
\end{tabular}

\section{\begin{tabular}{l} 
\\
$-0,25$ \\
0,24 \\
\hline
\end{tabular}} $\begin{array}{r}\quad 0,24 \\ -0,36 \\ -0,29 \\ -0,26 \\ \hline\end{array}$

$\begin{array}{rr}-0,37 & -0,26 \\ -0,26 & -0,22-0,32\end{array}$

$-0,26$

$\begin{array}{cc} & 0,39 \\ 0,28 & -0,24\end{array}$

\section{4}

$-\frac{3}{4}$

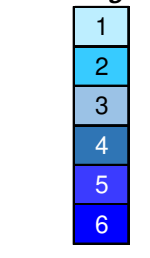

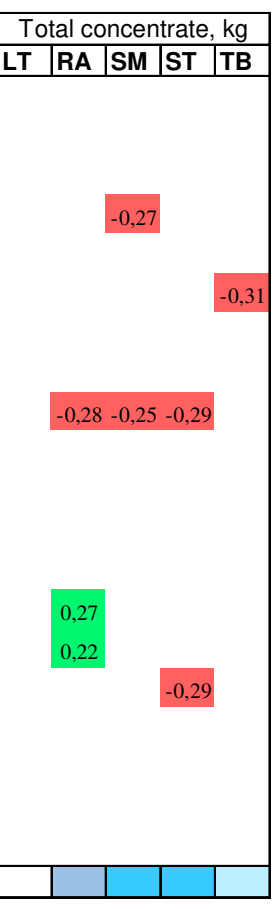

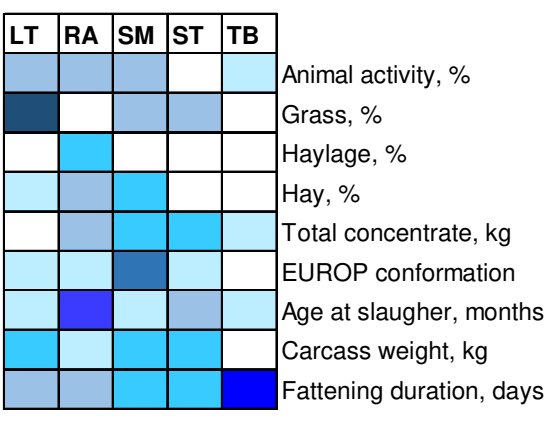

$-0,24$ 


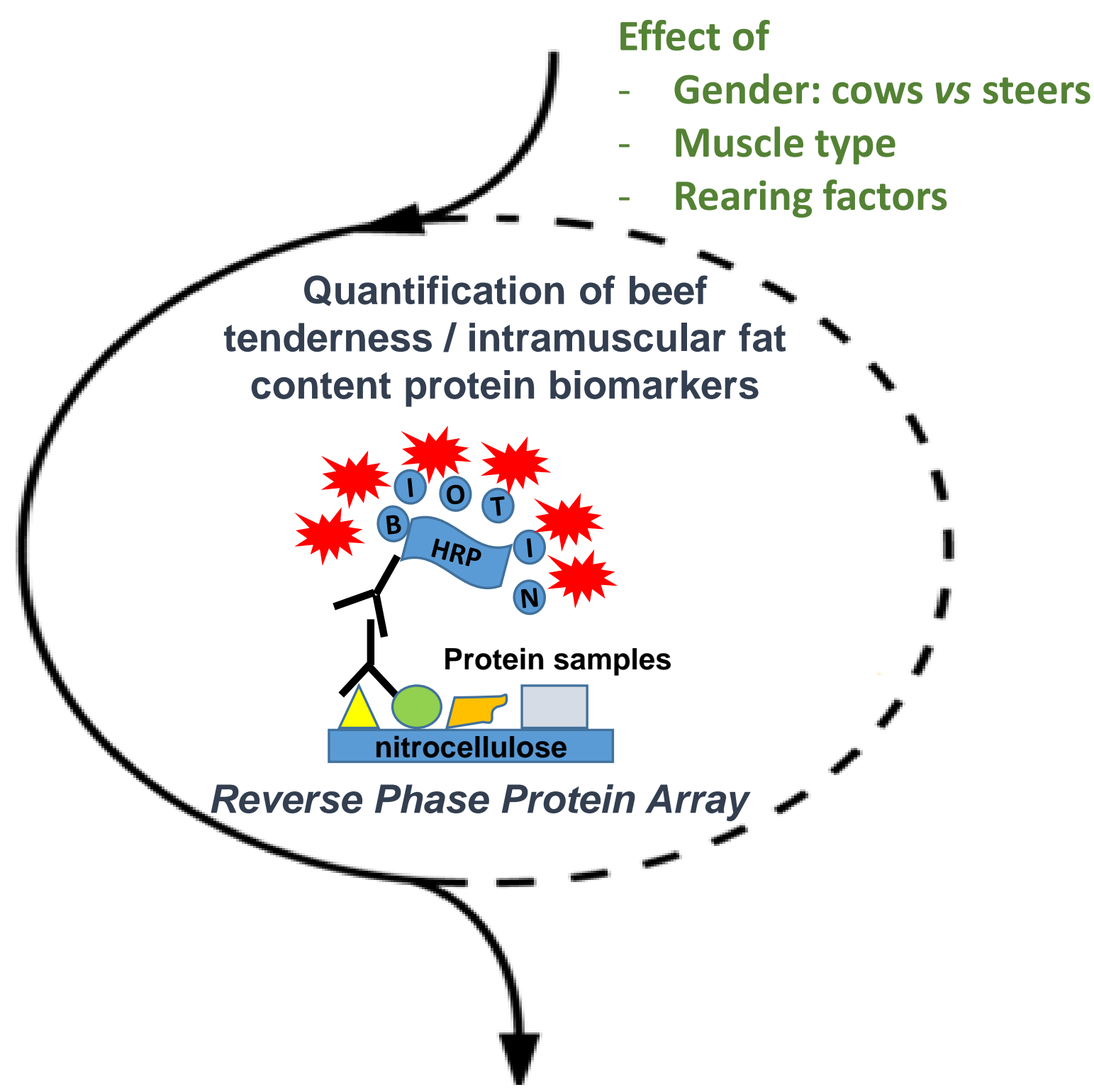

Management of beef meat qualities

by rearing practices 